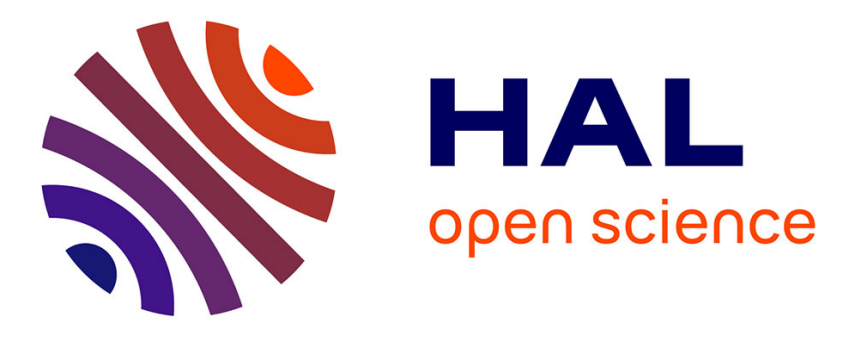

\title{
Exploring the impact of Cenomanian paleogeography and marine gateways on oceanic oxygen
}

Marie Laugié, Yannick Donnadieu, Jean-Baptiste Ladant, Laurent Bopp, Christian Ethé, François Raisson

\section{- To cite this version:}

Marie Laugié, Yannick Donnadieu, Jean-Baptiste Ladant, Laurent Bopp, Christian Ethé, et al.. Exploring the impact of Cenomanian paleogeography and marine gateways on oceanic oxygen. Paleoceanography and Paleoclimatology, 2021, 36 (7), pp.e2020PA004202. 10.1029/2020PA004202 . hal-03273816

\section{HAL Id: hal-03273816 https://hal.science/hal-03273816}

Submitted on 22 Jul 2021

HAL is a multi-disciplinary open access archive for the deposit and dissemination of scientific research documents, whether they are published or not. The documents may come from teaching and research institutions in France or abroad, or from public or private research centers.
L'archive ouverte pluridisciplinaire HAL, est destinée au dépôt et à la diffusion de documents scientifiques de niveau recherche, publiés ou non, émanant des établissements d'enseignement et de recherche français ou étrangers, des laboratoires publics ou privés. 


\section{Paleoceanography and Paleoclimatology}

\author{
RESEARCH ARTICLE \\ 10.1029/2020PA004202 \\ Key Points: \\ - Cenomanian paleogeography has \\ preconditioned the ocean on the \\ runup to the Oceanic Anoxic Event 2 \\ (OAE2) by controlling bottom water \\ oxygen \\ - A deep connection between the \\ Pacific and Central Atlantic oceans \\ is needed before OAE2 to explain the \\ Central Atlantic redox data \\ - The reconstructed Cenomanian \\ oceanic circulation is vigorous but \\ does not prevent significant parts of \\ the ocean to be anoxic
}

Supporting Information:

Supporting Information may be found in the online version of this article.

Correspondence to:

M. Laugié,

laugie@cerege.fr

Citation:

Laugié, M., Donnadieu, Y., Ladant, J.-B., Bopp, L., Ethé, C., \& Raisson, F. (2021). Exploring the impact of Cenomanian paleogeography and marine gateways on oceanic oxygen. Paleoceanography and Paleoclimatology, 36, e2020PA004202. https://doi. org/10.1029/2020PA004202

Received 25 DEC 2020 Accepted 14 JUN 2021

(C) 2021. American Geophysical Union. All Rights Reserved.

\section{Exploring the Impact of Cenomanian Paleogeography and Marine Gateways on Oceanic Oxygen}

\author{
Marie Laugié ${ }^{1}(D)$, Yannick Donnadieu ${ }^{1}$, Jean-Baptiste Ladant ${ }^{2}$, Laurent Bopp ${ }^{3}$, \\ Christian Ethé ${ }^{4}$, and François Raisson ${ }^{5}$ (D) \\ ${ }^{1}$ Aix Marseille Univ, CNRS, IRD, INRA, Coll. France, CEREGE, Aix-en-Provence, France, ${ }^{2}$ Laboratoire des Sciences du \\ Climat et de l'Environnement, LSCE/IPSL, CEA-CNRS-UVSQ, Université Paris-Saclay, Gif-sur-Yvette, France, ${ }^{3} \mathrm{LMD} /$ \\ IPSL, Ecole Normale Supérieure / PSL University, CNRS, Ecole Polytechnique, Sorbonne Université, Paris, France, \\ ${ }^{4}$ Institut Pierre-Simon Laplace, Sorbonne Université/CNRS, Paris, France, ${ }^{5}$ Total EP - New Exploration Concepts R\&D \\ Program, Pau, France
}

Abstract The Cenomanian-Turonian period recorded one of the largest disruptions to the oxygen and carbon cycles, the Oceanic Anoxic Event 2 (OAE2, $94 \mathrm{Ma}$ ). This event is global, yet paleo-reconstructions document heterogeneous ocean oxygenation states and sedimentary carbon contents, temporally and spatially, suggesting that several mechanisms are at play. To better understand the long-term controls on oceanic oxygen and the initial oxygenation conditions prevailing at the beginning of OAE2, we perform numerical simulations of the Cenomanian using the IPSCL-CM5A2 Earth System Model, which includes a marine biogeochemistry component. We examine the control of the biogeochemical states of the global and Central Atlantic oceans by the depth of the Central American Seaway (CAS). The simulations show that a vigorous ocean circulation existed during the Cenomanian before OAE2 and that dysoxia/ anoxia was caused by paleogeography rather than by ocean stagnation. The existence of restricted basins, disconnected from the deep global circulation and supplied with oxygen-depleted waters from Oxygen Minimum Zones of the surrounding basins, played a key role in the development of dysoxic/ anoxic regions. A comparison with redox-proxy data suggests that a deep connection existed between the Pacific and Central Atlantic prior to OAE2. A shallowing of the CAS may have contributed to the establishment of enhanced anoxia in the Central Atlantic, but cannot be the only OAE2 triggering factor. The paleogeographic configuration and that of gateways appear as major factors controlling the oceanic circulation and oxygen distribution, leading to extended low-oxygenated oceanic areas as prerequisite conditions necessary for the OAE2 to occur.

Plain Language Summary The Cenomanian-Turonian period, during the Cretaceous, recorded one of the largest ocean deoxygenation event, called the Oceanic Anoxic Event 2 (94 Myr ago). This event is global, however heterogeneous ocean oxygenation states and sedimentary carbon contents are registered, both temporally and spatially, suggesting that several mechanisms may be at play. To better understand the long-term controls on oceanic oxygen, we use Earth System Modeling to simulate paleoclimate, paleoceanography and marine biogeochemistry during the Cenomanian, with a special attention on the Central Atlantic and the impact of the depth of the Central American Seaway that connects Pacific and Central Atlantic oceans. Our simulations show that a vigorous ocean circulation was in place during the Cenomanian and that dysoxia/anoxia was caused by paleogeography rather than by ocean stagnation. A comparison with data in the Central Atlantic suggests that a deep connection existed between the Pacific and Central Atlantic prior to the oceanic anoxic event 2 and that a shallowing of this connection may have contributed to the establishment of enhanced anoxia in the Central Atlantic during the anoxic event. The paleogeographic configuration thus appears as a major long-term controller of the oceanic circulation and oxygen distribution.

\section{Introduction}

The Cenomanian-Turonian is a key period to study the oxygen and carbon cycles as it recorded one of their greatest disturbance, known as the Oceanic Anoxic Event 2 (OAE2) and characterized by the widespread deposition of organic-rich sediments (Arthur et al., 1987; Jenkyns, 2010; Owens et al., 2018). A positive carbon isotopic excursion (CIE) associated with OAE2 delimits the event in the lithological succession and 
shows that this event was global and rapid (between 400 kyr and 1 Myr; Gangl et al., 2019; Jenkyns, 2010; Jones et al., 2019; Sageman et al., 2006; Voigt et al., 2008). However, the associated carbon enrichment is strongly variable, both spatially, with content of total organic carbon (TOC) varying between $0 \%$ to $50 \%$ during OAE2 (Owens et al., 2018), but also temporally, with sites documenting the onset of deposition of organic-rich sediments prior to OAE2, particularly in the Southern Central Atlantic (Kuypers et al., 2002; Montoya-Pino et al., 2010; Owens et al., 2012; Trabucho Alexandre et al., 2010; Westermann et al., 2014).

Proxy data of redox sensitive trace elements also document heterogeneous oxygenation state before and during OAE2 (van Helmond, Ruvalcaba Baroni, et al., 2014), with some areas exhibiting for example anoxia before OAE2. A diachronism between CIE and carbon enrichment was also shown with highest TOC contents prevailing before and after CIE, but not during (i.e., indicating oxic conditions during OAE2), suggesting a partial decoupling of CIE and anoxia (Eldrett et al., 2014; Lowery, Cunningham, et al., 2017; Lowery, Leckie, et al., 2017). It has been suggested that the CIE was triggered by increased organic carbon burial, following an abrupt and massive volcanism episode (Du Vivier et al., 2014; Turgeon \& Creaser, 2008) that drove an increase in atmospheric $\mathrm{pCO}_{2}$ (Barclay et al., 2010; Bice et al., 2006) and an amplified hydrological cycle leading to increased nutrient inputs to the ocean (Blättler et al., 2011; Jenkyns et al., 2017; Nederbragt et al., 2004; van Helmond, Sluijs, et al., 2014; Van Helmond et al., 2015; Pogge Von Strandmann et al., 2013; Ruvalcaba Baroni et al., 2014). Other studies have shown that the CIE was also modulated by orbital controls determining the exact timing of its beginning and termination (Batenburg et al., 2016; Li et al., 2017; Mitchell et al., 2008; Wagner et al., 2004). The decoupling of CIE and anoxia, as well as the spatial and temporal variations in carbon content and ocean redox conditions suggest that other mechanisms, in the longer term, are at play and act on temporal and spatial scales different from those suggested for CIE alone.

Unraveling the short-term controls (1,000-year timescale) on oxygenation and carbon burial during the OAEs appears thus challenging without a good understanding of the long-term control (million-year timescale) on oceanic oxygen and of the oxygenation conditions that existed at the beginning of the OAEs. The Cretaceous ocean has long been considered stratified and stagnant, due to the coeval greenhouse climate (Degens \& Stoffers, 1976; Erbacher et al., 2001; Sinninghe Damste \& Koster, 1998). Such a sluggish circulation was invoked to explain sea-floor anoxia and black shale deposition, but more recent observational and modeling studies have shown that a vigorous oceanic circulation was in place, with an active ventilation of the deep-ocean (Donnadieu et al., 2016; Du Vivier et al., 2014; Ladant et al., 2020; MacLeod et al., 2008; Martin et al., 2012; Monteiro et al., 2012; Mourlot et al., 2018; Poulsen et al., 1998; Soares et al., 2014; Thiéblemont et al., 2020; Trabucho Alexandre et al., 2010; Zheng et al., 2013). Other controls, such as long-term changes in paleogeography and in particular in the geometry of marine gateways, have thus been invoked to explain changes in oceanic circulation and ocean deoxygenation (Donnadieu et al., 2016; Dummann, Steinig, Hofmann, Flögel, et al., 2020; Poulsen et al., 2001; Trabucho Alexandre et al., 2010). Dummann, Steinig, Hofmann, Flögel, et al. (2020) have in particular demonstrated that the shallow Falkland Plateau and Maurice Ewing Bank exerted a first-order control on ocean anoxia in the Southern Atlantic during the Aptian OAE1a ( 120 Ma), an event similar to the OAE2 in terms of mechanisms but presenting a different geographical distribution of black shales. The particular geometry of Falkland Plateau and Maurice Ewing Bank provided favorable conditions in the Southern Atlantic, without which organic carbon burial would not be possible during OAE1a (Dummann, Steinig, Hofmann, Flögel, et al., 2020).

During the Cenomanian-Turonian, the Central Atlantic basin, from where numerous data document OAE2, is surrounded by five gateways, namely the Equatorial Atlantic Gateway (EqAG) in the South, the CAS in the West, the Western Interior Seaway (WIS) in the North-West, the East Greenland Seaway (EGS) in the NorthEast and the Tethys Seaway in the East (Figure 1). The paleodepths of the WIS, EGS, and EqAG are relatively well-constrained, with very shallow bathymetry for the WIS and EGS ( $<200 \mathrm{~m}$; Gernigon et al., 2020; Martinson et al., 1998) and shallow bathymetry for the EqAG (<800 m; Ye et al., 2017). The Tethys Seaway paleodepth is more uncertain (Nouri et al., 2016), as well as the paleodepth of the CAS that is suggested to vary concomitantly to OAE2 due to the Caribbean Large Igneous Province (CLIP) activity and the formation of the Caribbean Plateau (Buchs et al., 2018). There is some evidence supporting a causal relationship between the intense volcanic activity associated with the CLIP development in the Late Cenomanian and the OAE2 (Joo et al., 2020; Turgeon \& Creaser, 2008). Recent work also demonstrated that the depth of the CAS can exert a significant role on the oceanic circulation during the Cretaceous (Donnadieu et al., 2006, 2016; 

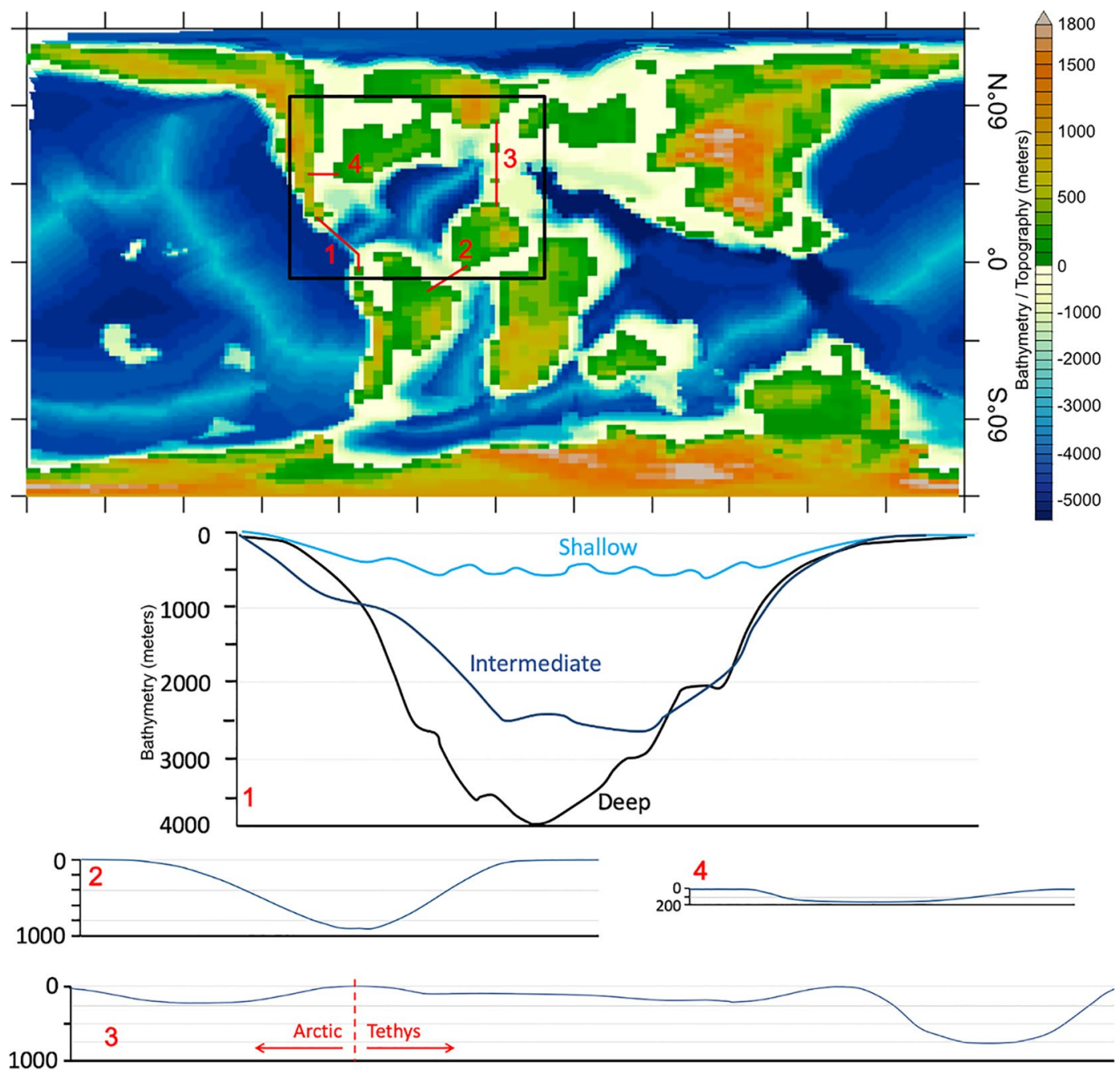

Figure 1. Cenomanian-Turonian paleogeographic configuration and bathymetric profiles of main gateways surrounding the Central Atlantic: (a) Central American Seaway (CAS). The three configurations correspond to different simulations. (b) Equatorial Atlantic Gateway (EqAG). (c) Tethyan and Arctic seaways. (d) Western Interior Seaway (WIS). The black box corresponds to the region of interest of Figure 6.

Ladant et al., 2020; Monteiro et al., 2012; Topper et al., 2011; Trabucho Alexandre et al., 2010) and, consequently, can strongly impact the distribution of dissolved oxygen in the ocean (Kerr \& Kerr, 1998) and affect rates of organic matter preservation (Monteiro et al., 2012). Although it is unlikely that changes in gateway bathymetry are directly responsible for triggering OAE2 because they act on longer timescales, changes in the CAS depth and geometry on the runup to OAE2 may have preconditioned and/or contributed to the establishment of anoxic conditions in the deep Central Atlantic Ocean through a reorganization of deepocean currents. To date, however, the dynamics of oceanic oxygen during the Cenomanian and OAE2 has only been investigated using box models (Flögel et al., 2011; Ruvalcaba Baroni et al., 2014) and Earth System Models of Intermediate Complexity (EMIC; Monteiro et al., 2012).

Here, we examine the sensitivity of oceanic dissolved oxygen to a mid-Cretaceous paleogeography and to the CAS geometry using numerical simulations of the Cenomanian ocean with the IPSL-CM5A2 Earth System Model (ESM) (Sepulchre et al., 2020), which includes the marine biogeochemistry model PISCES (Aumont et al., 2015). We first analyze the long-term impact of a baseline Cenomanian-Turonian paleogeography (with the CAS open to deep circulation) on oceanic circulation and oxygen at the global scale. In a second step, we test the impact of changes in ocean dynamics on dissolved oxygen by performing two sensitivity experiments with intermediate and shallow CAS configurations. Results are focused on the Central 
Atlantic to investigate the consequences on dissolved oxygen of oceanic circulation changes arising from the different gateway geometries. Finally, the comparison with redox proxy data provides a better understanding of the long-term paleogeographic control on oceanic oxygen during the Cenomanian, as well as an estimate of the pre-OAE2 oxygenation state, which will serve as a basis for further unraveling the triggering mechanisms of OAE2 and the associated strong carbon burial.

\section{Model Description and Experimental Design}

\subsection{IPSL-CM5A2 Earth System Model}

The IPSL-CM5A2 Earth System Model (Sepulchre et al., 2020) is an updated version of IPSL-CM5A-LR developed at IPSL (Institut Pierre-Simon Laplace) within the CMIP5 framework (Dufresne et al., 2013). IPSL-CM5A2 is composed of the LMDZ atmospheric model (Hourdin et al., 2013), the ORCHIDEE land surface and vegetation model (including the continental hydrological cycle, vegetation and the land carbon cycle; Krinner et al., 2005), and the NEMO ocean model (Madec and the NEMO Team, 2016), including the LIM2 sea-ice model (Fichefet \& Maqueda, 1997) and the PISCES-v2 marine biogeochemistry model (Aumont et al., 2015). The ocean and atmospheric components are synchronized via the OASIS coupler (Valcke et al., 2006) and the XIOS input/output parallel library is used to read and write data. The atmospheric grid has a horizontal resolution of $96 \times 95$, (equivalent to $3.75^{\circ}$ in longitude and $1.875^{\circ}$ in latitude) and 39 uneven vertical levels. ORCHIDEE shares the same horizontal resolution, whereas the oceanic grid has 31 uneven vertical levels (from $10 \mathrm{~m}$ depth at the surface to $500 \mathrm{~m}$ at the bottom) and a nominal horizontal resolution of $2^{\circ}$, enhanced to up to $0.5^{\circ}$ in latitude in the $20^{\circ} \mathrm{S}-20^{\circ} \mathrm{N}$ latitudinal band. NEMO uses a tripolar grid to overcome the North Pole singularity (Madec \& Imbard, 1996). For a more detailed description of the model and its different components, see Sepulchre et al. (2020).

\subsection{PISCES Marine Biogeochemistry Model}

The PISCES model (Pelagic Interactions Scheme for Carbon and Ecosystem Studies, Aumont et al., 2015) simulates the lower trophic levels of marine ecosystems (nanophytoplankton, diatoms, microzooplankton and mesozooplankton), carbonate chemistry and the biogeochemical cycles of carbon, oxygen, and of the main nutrients: phosphorus, nitrogen, iron and silica. In PISCES, dissolved oxygen is produced in the ocean according to phytoplankton net primary production and consumed by zooplankton heterotrophic respiration, oxic remineralization of organic matter and nitrification (see Aumont et al., 2015 for detailed equations of all these terms). Dissolved oxygen is also exchanged at the air-sea interface using the parameterization of Wanninkhof (1992). Note that the atmospheric concentration of di-oxygen is set to a fixed ratio of 0.21. As in Bopp et al. (2017), we decompose dissolved oxygen into the $\mathrm{O}_{2}$ saturation $\left(\mathrm{O}_{2} \mathrm{sat}\right)$ and Apparent Oxygen Utilization (AOU) components. $\mathrm{O}_{2}$ sat only depends on seawater temperature and salinity. At the surface of the ocean, the concentration of dissolved oxygen is very close to its saturation state, such that $\left[\mathrm{O}_{2}\right]=\mathrm{O}_{2}$ sat. AOU represents the quantity of oxygen that has been consumed by biogeochemical processes on the trajectory of a given water-mass from the ocean's surface, and thus integrates both a biological and a ventilation signature. The three terms are linked as follows: $\left[\mathrm{O}_{2}\right]=\mathrm{O}_{2} \mathrm{sat}-\mathrm{AOU}$ (Bopp et al., 2017).

In the water column, PISCES explicitly represents two pools of organic matter particles that differ in their average size (i.e., large and small particles) and hence in their respective sinking speed, as well as a pool of semi-labile dissolved organic matter. The particle pools are degraded into the dissolved one as a function of temperature and oxygen concentrations. Dissolved organic matter undergoes oxic remineralization or denitrification depending on local oxygen levels. The remineralization and denitrification rates are function of temperature, oxygen and nitrate concentrations, and of the bacterial activity and biomass (see Aumont et al., 2015, Equations 33a and 33b). When reaching the ocean floor in the form of particles, organic matter is permanently buried or degraded by sedimentary denitrification or oxic remineralization. The proportion of buried carbon is dependent on the organic carbon flux at the bottom and is computed according to Dunne et al. (2007). The fraction of sedimentary denitrification versus oxic remineralization is computed using the meta-model of Middelburg et al. (1996). Degraded organic carbon is then released into the ocean bottom level in the form of DIC. Ocean bottom concentrations of dissolved oxygen and nitrate are also 
consumed to account for sedimentary oxic remineralization and denitrification, respectively (see also Aumont et al., 2015, Equations 88-90).

We also used an additional inert artificial tracer allowing to compute the age of water masses, corresponding to the time spent since last surface contact (Bopp et al., 2017).

\subsection{Experimental Design}

\subsubsection{Boundary and Initial Conditions}

The baseline and sensitivity simulations share the Cenomanian-Turonian (CT) land-sea configuration (Figure 1) of Sewall et al. (2007), in which the bathymetry from Müller et al. (2008) is implemented, in order to represent deep-oceanic topographic features, such as ridges, that are absent from the Sewall paleogeographic configuration. The $p \mathrm{CO}_{2}$ concentration is fixed at $1,120 \mathrm{ppm}$, that is, four times the pre-industrial atmospheric level (PAL), which is a value suggested by $\mathrm{CT} p \mathrm{CO}_{2}$ reconstructions (e.g., Wang et al., 2014), and which has been shown to reasonably reproduce the mean CT climate in IPSL-CM5A2 simulations (Laugié et al., 2020). Vegetation is assigned along latitudinal bands as described in Laugié et al. (2020) and a mean soil color and texture is prescribed uniformly to all continents. Polar ice sheets are removed and replaced by a brown bare soil after adjusting the topography to account for isostatic rebound. The solar constant is reduced to a CT value of 1353.36 W.m ${ }^{-2}$ (Gough, 1981). Orbital parameters are set to their modern value. The global oceanic budgets of all macro-nutrients (nitrate, phosphate and silicate) are also initialized to their modern values, first because Cenomanian nutrient budgets are unknown, and second because it allows to isolate the effect of ocean dynamics on the intensity of ocean anoxia while mimicking the tectonic drift of the CLIP across the Central American Seaway by shallowing the depth of the gateway. The global nutrient budgets are not allowed to vary in this version of PISCES, which implies that, at any time in the model integration, nutrient inputs and outputs are balanced at the global scale regardless of the ocean biogeochemical state. The spatial distribution of nutrients changes according to ocean circulation and productivity but the global mean nutrient concentrations are restored to their modern values.

The three simulations present different paleobathymetric configurations for the Central American Seaway (CAS; Figure 1). The baseline DeepCAS simulation exhibits a deep connection ( 4,000 m depth) between the Pacific and Central Atlantic (Figure 1). The CAS depth is reduced to intermediate $(\sim 2,500 \mathrm{~m})$ and shallow depths $(\sim 300 \mathrm{~m})$ in the IntermediateCAS and ShallowCAS simulations, respectively (Figure 1). Note that the three configurations are hypothetical; the Deep and Shallow CAS constituting possible bathymetric end-members. All other boundary conditions are identical for the three simulations. The simulations are initialized with warm idealized conditions adapted from those described in Lunt et al. (2017). The constant initial salinity field is set to 34.7 PSU, and ocean temperatures are initialized with the depth-dependent distribution of Laugié et al. (2020).

\subsubsection{Equilibrium State}

The baseline DeepCAS simulation is first run for 3,000 years with IPSL-CM5A2. From the end state of this first simulation, we branch the two CAS sensitivity simulations and integrate them for 3,500 years. The baseline simulation is also extended for another 3,500 years. Finally, because the biogeochemical equilibrium of the ocean typically requires a longer spin-up (Séférian et al., 2016), we extend each simulation over an additional 3,000-year period by performing "offline” PISCES-only simulations. In those offline simulations, PISCES is forced by using the last 100-year climatology (e.g., monthly means of ocean temperature, salinity, currents, incoming radiation, ....) from each of the three coupled climate simulations. This strategy allows deep-ocean biogeochemistry, and in particular seafloor oxygen concentrations, to reach a final state closer to equilibrium. Climate and biogeochemical results are discussed using climatological averages calculated over the last 100 years of IPSL-CM5A2 and PISCES integrations, respectively.

The equilibrium for the three IPSL-CM5A2 simulations is assessed using surface and deep oceanic temperatures (Figures S1a and S1b) and the intensity of the global meridional stream function (Figure S1c). Both surface and deep temperatures have reached a near equilibrium state with temporal drifts estimated at less than $0.05^{\circ} \mathrm{C} /$ century (Table S1) during the last 1,000 years of the climate model integration. The meridional 
streamfunction is also well equilibrated with stable maximum intensity of around $17 \mathrm{~Sv}$ during the last 2,000 years of the simulation.

Furthermore, the three PISCES simulations exhibit negligible drifts in deep ocean oxygen concentrations (Figure S1d) after 3,000 years of offline simulations (Table $\mathrm{S} 1 ;<0.1 \mathrm{mmol} / \mathrm{m}^{3} /$ century).

\subsection{Redox Data}

The simulated results are compared to reconstructions of oceanic oxygen state inferred from pre-OAE2 and OAE2 data. Our data compilation is built from the databases of Monteiro et al. (2012) and Owens et al. (2018). The oxygenation states documented in these two databases are essentially inferred from TOC contents, which are a function of bottom water oxygen, but are also influenced by other parameters such as the organic matter flux to the seafloor, the dilution with inorganic matter or diagenetic processes. In our compilation, we thus selected only data points for which other indicators than TOC were available, such as analysis of redox sensitive trace elements or presence/absence of benthic biota, which are direct indicators of bottom water oxygenation. We also chose to only select data for which an estimation of the paleowater depth exists in order to be comparable with our model results. The data points are distributed to their paleolocation using the GPlates software (Qin et al., 2012) and the global plate rotation model of Scotese (2016). In case of an inconsistency between the calculated paleoposition and the paleowater depth, data points are then moved to the nearest location with a correct paleodepth in the model (See Supplementary information).

\section{Results}

In a first step, we describe the major patterns of ocean circulation and oxygen distribution at the global scale, using the DeepCAS simulation. Results from the IntermediateCAS and ShallowCAS simulations are very similar to DeepCAS at the global scale, with the change in CAS depth mostly affecting the Central Atlantic. In a second step, we focus on the Central Atlantic and analyze the regional impact of the CAS on ocean circulation and oxygen distribution in the three simulations. In the following, we distinguish three oxygen classes: oxic waters $\left(\left[\mathrm{O}_{2}\right]>62.5 \mathrm{mmol} / \mathrm{m}^{3}\right)$, dysoxic waters $\left(6.5<\left[\mathrm{O}_{2}\right]<62.5 \mathrm{mmol} / \mathrm{m}^{3}\right)$ and anoxic waters $\left(\left[\mathrm{O}_{2}\right]<6.5 \mathrm{mmol} / \mathrm{m}^{3}\right)$.

\subsection{Ocean Circulation and Oxygen Distribution in the Global Ocean}

\subsubsection{Upper and Intermediate Ocean}

Upper ocean waters $(0-100 \mathrm{~m})$ are generally close to dissolved oxygen saturation, which means that oxygen concentrations are mainly determined by surface temperature and its influence on oxygen solubility (Figure 2a). The Cenomanian upper ocean is characterized by elevated temperatures and a reduced equatorto-pole gradient (Laugié et al., 2020; Norris et al., 2002; O'Brien et al., 2017; Robinson et al., 2019; Tabor et al., 2016). In the low latitudes ( $<35^{\circ}$ of latitude), because oxygen solubility decreases with temperature, $\mathrm{O}_{2}$ saturation is reduced to an average of $198 \mathrm{mmol} / \mathrm{m}^{3}$, for an average temperature of $30.7^{\circ} \mathrm{C}$. In comparison, the mean temperature in the low latitudes in the pre-industrial simulation of Laugié et al. (2020) is $22.2^{\circ} \mathrm{C}$, with a corresponding $\mathrm{O}_{2}$ saturation at $228 \mathrm{mmol} / \mathrm{m}^{3}$. In the high latitudes $\left(>60^{\circ}\right.$ of latitude), $\mathrm{O}_{2}$ saturation reaches higher values $\left(\sim 300 \mathrm{mmol} / \mathrm{m}^{3}\right)$ than in the low latitudes but, again, with a large offset compared to preindustrial high-latitude saturation levels $\left(\sim 370 \mathrm{mmol} / \mathrm{m}^{3}\right)$. Subsurface oxygen concentrations ( $<600 \mathrm{~m}$ of water depth) also exhibit a latitudinal gradient (Figure $2 \mathrm{~b}$ ) but they are more impacted by ocean dynamics, in particular in regions of strong vertical currents (e.g., equatorial upwelling, Figure 2b). Specifically, in the Central Atlantic and Eastern Equatorial Pacific, the model simulates complete anoxia in the subsurface and up to the base of the photic zone. At intermediate depths (600-1,600 m of water depth), oxygen concentration is globally more homogeneous in the ocean except in the South Pacific and Central Atlantic (Figure 2c). South Pacific waters remain well-oxygenated from the surface to the bottom because this region is the source of deep-water in our Cenomanian simulations. In contrast, the Central Atlantic is bathed by oxygen-depleted waters (Figure 2c), whose origin is described in more details in Section 3.2. 

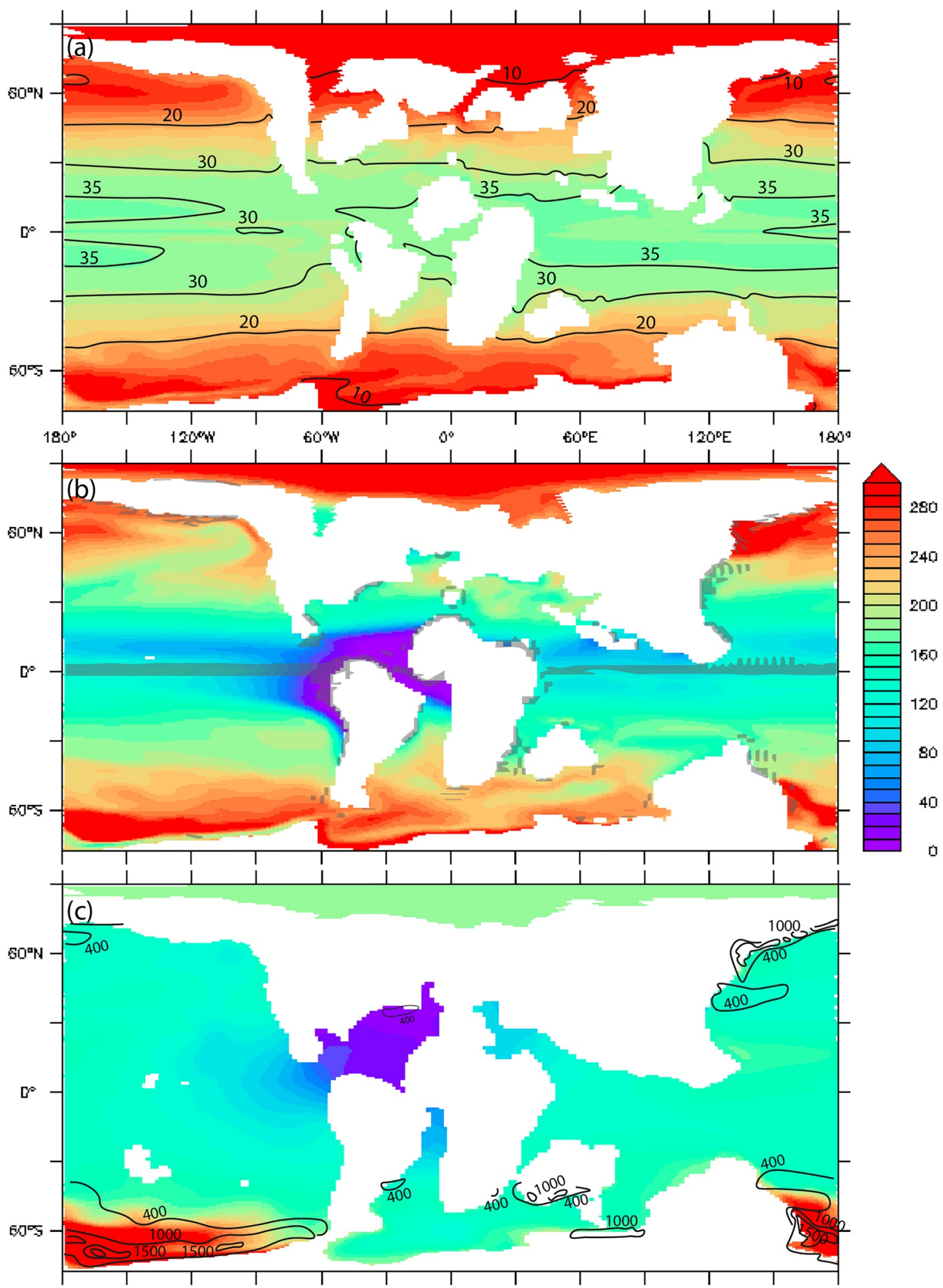

Figure 2. Oxygen concentration for the DeepCAS simulation (in mmol. $\mathrm{m}^{-3}$ ); (a) At the surface level of the model $(0-10 \mathrm{~m})$ with contours of sea-surface temperatures $\left({ }^{\circ} \mathrm{C}\right)$; (b) At $180 \mathrm{~m}$ depth with areas of strong upwelling (gray shaded areas, vertical speed $>8 \mathrm{~cm} /$ day), and (c) At $700 \mathrm{~m}$ depth with the mixed layer depth as contours (meters). 


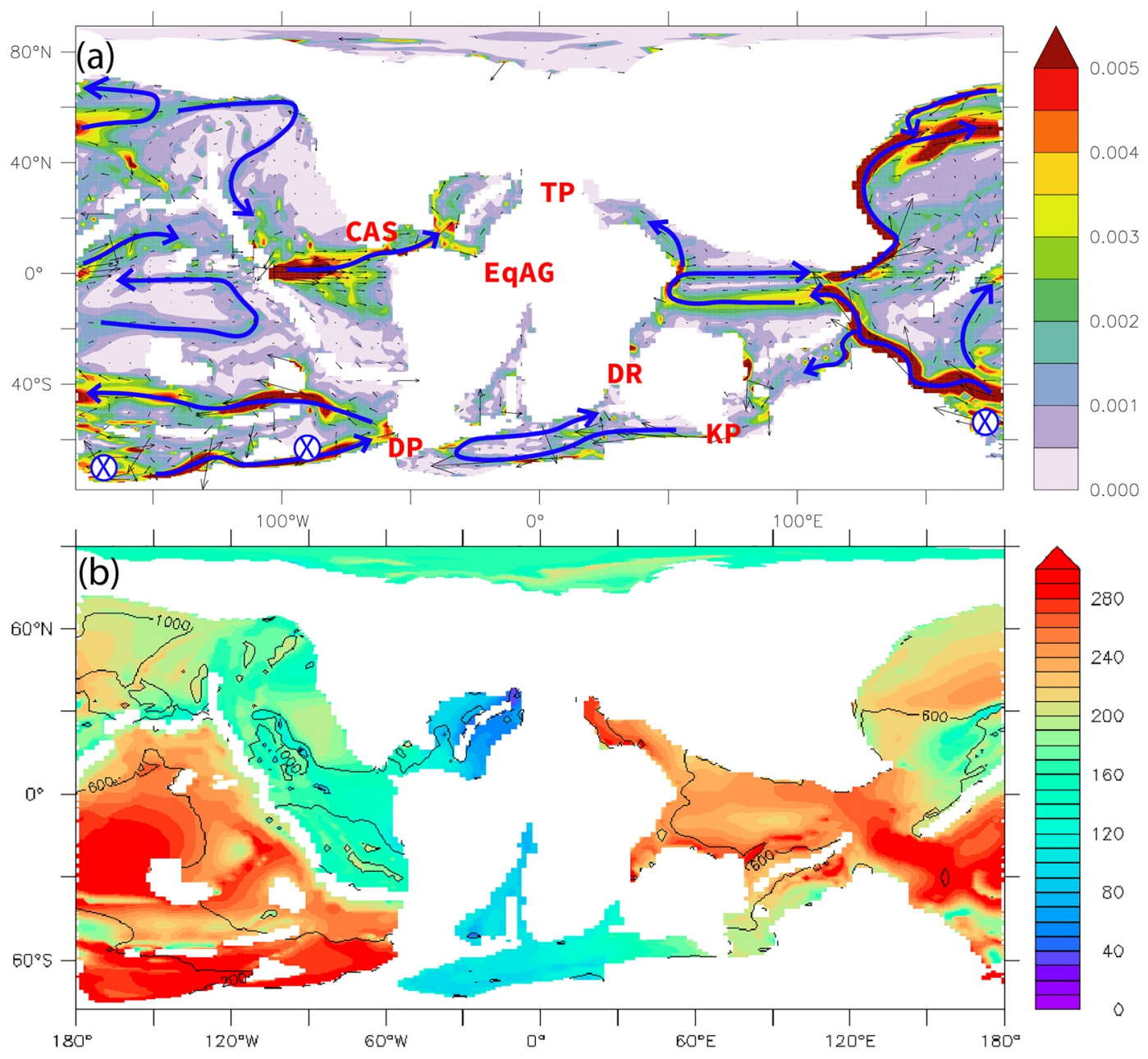

Figure 3. Oceanic circulation and oxygenation for the DeepCAS simulation. (a) Deep-currents velocity on the seafloor for areas where water depth $>3,000 \mathrm{~m}(\mathrm{~m} / \mathrm{s})$. Blue crosses correspond to areas of deep-water formation. Submarine topographic features are labeled in red: TP: Tethyan platforms, CAS: Central American Seaway, EqAG: Equatorial Atlantic Gateway, DR: Davie Ridge, DP: Drake Passage, KP: Kerguelen Plateau. (b) Oxygen concentrations on the seafloor for areas where water depth $>3,000 \mathrm{~m}(\mathrm{mmol} / \mathrm{m} 3)$. Black contours correspond to the water age at the same depth (years).

\subsubsection{Deep Ocean}

The deep-sea oxygen distribution is controlled at first order by the location of deep-water formation sites and by the bathymetry (Figure 3a). In our simulations, deep-water formation sites are only located in the South Pacific Ocean, although intermediate-water formation takes place in the North Pacific Ocean (Figure 2c). The South Pacific deep convection feeds a global meridional overturning circulation (MOC) of maximum intensity at $18 \mathrm{~Sv}$, similar to the modern Atlantic MOC (18 Sv; Talley et al., 2003). Note that the intensity of the MOC appears only weakly sensitive to the depth of the CAS (Figure S2). The simulated Cenomanian MOC reaches the abyssal ocean and suggests that the Cenomanian global circulation was vigorous, contrary to the well-anchored image of a sluggish ocean (Degens \& Stoffers, 1976; Erbacher et al., 2001; Sinninghe Damste \& Koster, 1998) but in agreement with results from other recent model simulations (Donnadieu et al., 2016; Ladant et al., 2020; Trabucho Alexandre et al., 2010).

From their origin in deep-water formation sites in the South Pacific, deep waters flow northward into the Neotethys and Equatorial Pacific Oceans (Figure 3a). The deep Neotethys waters then circulate back to the Pacific to flow north of the mid-Pacific ridge and toward the North-Eastern Pacific. Pacific deep waters ultimately end up in the Central Atlantic whereas the deep South Atlantic is restricted from the global 


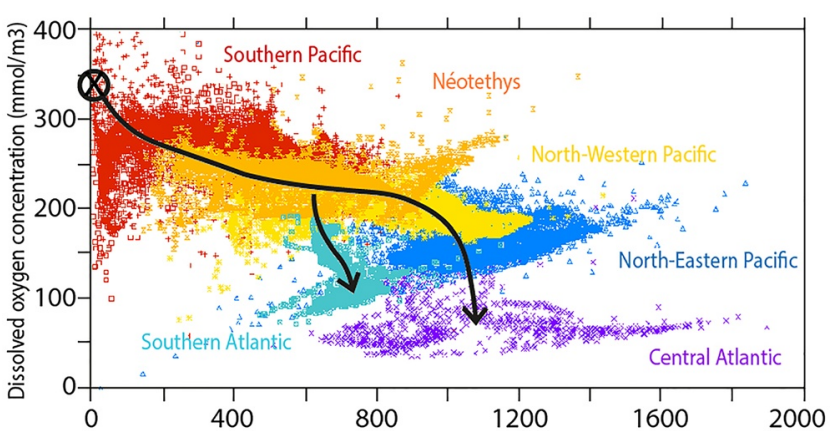

Figure 4. Plot of water age (years) versus oxygen concentration $\left(\mathrm{mmol} / \mathrm{m}^{3}\right)$ for water depth $>3,000$. Dots are colored by basin. Deep-water formation occurs in the Southern Pacific (Black cross) and black arrows indicate the two main circulation pathways through the basin. circulation by four submarine topographic barriers that are the Kerguelen Plateau, the Davie Ridge, the Equatorial Atlantic Gateway, and the Drake passage (Figure 3a). This pattern of deep circulation leads to interbasin gradients in deep ocean oxygen concentrations and water mass age (Figure 3b); the degree of oxygenation of deep waters appearing well correlated with their age (Figure 4; Figure S3). The younger and most oxygenated waters are indeed found in the South Pacific and in the Neotethys Ocean. The South Atlantic and North-Eastern Pacific exhibit reduced oxygenation and older water masses, and the Central Atlantic is the oldest and most oxygen-depleted deep basin. The disconnection of the South Atlantic from the global deep circulation also explains the presence of old and oxygen-depleted water masses in this basin (Figure 3b).

Interestingly, a similarly restricted deep circulation, confined to the $\mathrm{Pa}$ cific and Neotethys Oceans due to bathymetric barriers, is also simulated in a Cenomanian simulation with the CCSM4 ESM (Ladant et al., 2020), suggesting that submarine topographic barriers are major controllers of the deep circulation and thus of dissolved oxygen in the deep ocean.

\subsubsection{Relationship Between Oxygen and Marine Productivity}

In our simulations, there is an obvious correlation between ocean dynamics and deep ocean oxygenation (Figure 4), indicating that older waters are the most oxygen-depleted ones. There is not such a clear correlation between marine productivity and deep oxygen concentrations, but interesting insights can be drawn from oxygen-productivity cross plots calculated in different regions of the ocean with distinct oxygen dynamics in the water column (Figure 5).

The meridional surface oxygen gradient is evident from the vertical oxygen profiles (Figure 5a). High-latitude locations (Profiles 1 and 3) exhibit high oxygen levels in the surface due to low temperatures whereas lower-latitude profiles show lower surface values (Profiles 2, 4, 5, 6).

Profile 1 is located in a deep-water formation area, with a low marine productivity. Deep-convection brings oxygen down to seafloor, and high oxygen values are found throughout the whole water column (Figure 5a). In contrast, albeit at the same latitude but in the Northern Hemisphere, the Profile 3 is located close to a region of intermediate water formation with seasonal primary production (Figures $5 \mathrm{~b}$ and $5 \mathrm{c}$ ). Limited convection and slightly higher productivity values impose a strong vertical gradient in oxygen between 300 and 1,000 $\mathrm{m}$ and reduces intermediate to deep oxygen levels. Nonetheless, these two regions can be viewed as "low productivity-high oxygen" areas.

Profile 2 and 6 are located in the subtropics in low productivity areas (Figure 5c). Marine productivity is low because of poor nutrient availability, which limits carbon export and oxygen consumption at depth. However, elevated upper ocean temperatures reducing $\mathrm{O}_{2}$ saturation leads to moderate surface and intermediate oxygen levels ("low productivity-low oxygen" region). In the deep ocean, those 2 oxygen profiles display a divergent trend. Profile 2 is located directly north of the deep-water formation area, from where oxygenated waters circulate. Oxygen concentrations in Profile 2, therefore, increase below 2,300 m (Figure 5a). Profile 6 is instead located in the South Atlantic away from well-oxygenated deep-water sources, which explains the continuous decrease of oxygen concentrations with depth (Figure 5a).

In contrast to the profiles discussed above, which are located in open ocean sectors of the Pacific and South Atlantic Oceans, Profiles 4 and 5 are more representative of coastal settings of the Central Atlantic basin. At these two locations, marine productivity is very high and leads to an intense export of organic matter and high oxygen utilization at depth. Hence, intermediate and deep ocean oxygen concentrations fall below the dysoxic threshold and, for Profile 5, even below the anoxia threshold ("high productivity-low oxygen” regions). The differences between both profiles are explained by vertical ocean dynamics (Figure S4). Profile 5 is indeed located in a major upwelling area whereas the site of Profile 4 experiences seasonal deepening of the mixed-layer and is thus a sinking area for upper ocean waters. Waters remain oxic only above $100 \mathrm{~m}$ in Profile 5 because upwelling supplies nutrient-rich and oxygen-depleted waters to the surface (Figure S5), which fuels productivity and enhances oxygen depletion. At the location of Profile 4, deep 


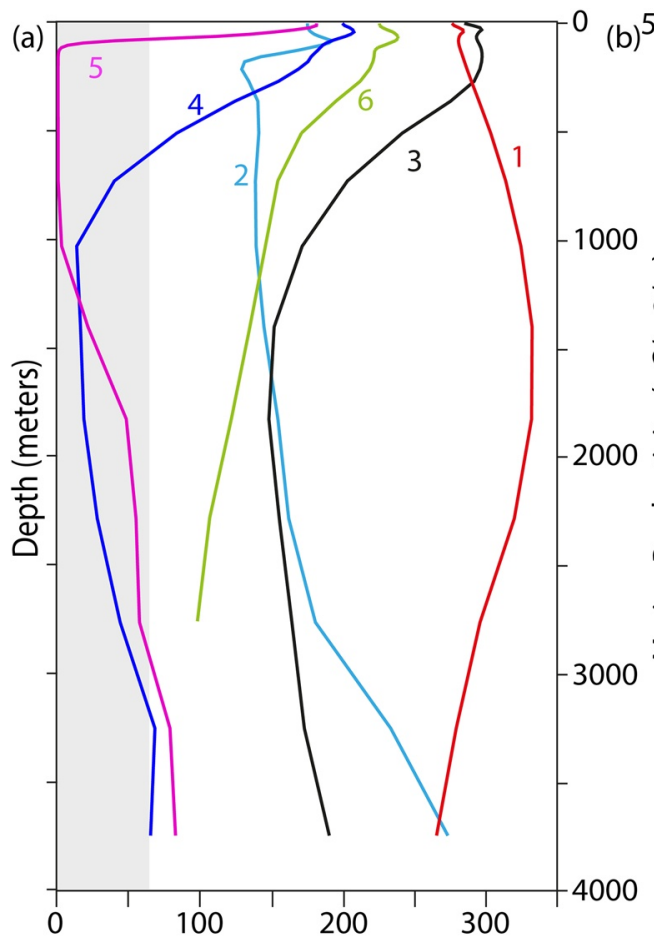

Dissolved oxygen concentration $(\mathrm{mmol} / \mathrm{m} 3)$

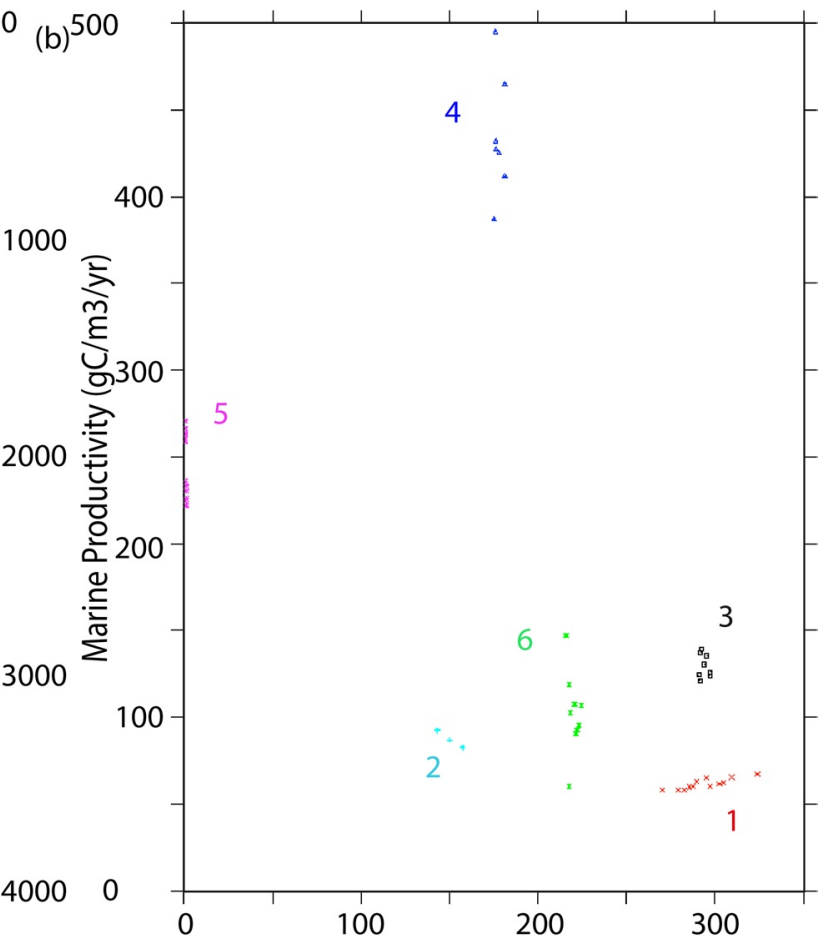

Dissolved oxygen concentration $(\mathrm{mmol} / \mathrm{m} 3)$

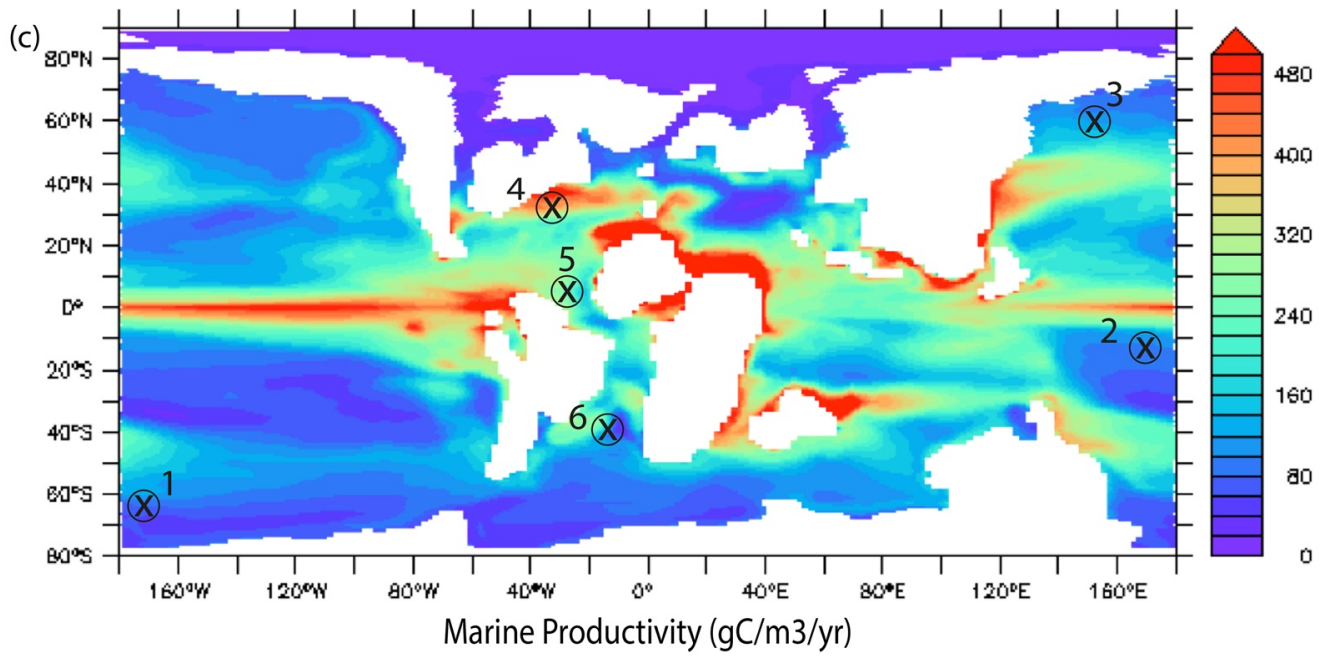

Figure 5. (a) Vertical profiles in oxygen concentrations for the DeepCAS simulation. Locations are indicated on (c). (b) Marine productivity integrated over the whole water column $\left(\mathrm{gC} \cdot \mathrm{m}^{-3} \cdot \mathrm{yr}^{-1}\right)$ versus oxygen concentration (integrated over the first $200 \mathrm{~m}$ of water depth) plotted for locations around each profile of (a), covering $-2 /+2$ decimal degrees in longitude and latitude around the profile. (c) Marine productivity integrated over the whole water column $\left(\mathrm{gC}_{\mathrm{m}} \mathrm{m}^{-3} \cdot \mathrm{yr}^{-1}\right)$ and locations of profiles.

coastal upwellings also allow nutrient-rich waters to reach the photic zone but the seasonal MLD deepening carries dissolved oxygen down the water column, which increases the remineralization potential. Increased remineralization increases the nutrient supply and boosts marine primary production to levels higher than at Profile 5. Deeper in the water column, both sites are bathed by intermediate and deep waters originating from the Pacific and exhibit similar oxygen concentrations. However, these last findings about Profiles 4 and 5, and the oxygen dynamics in the Central Atlantic more generally, are meaningful in a context of CAS open to deep circulation but are significantly altered with a shallower CAS configuration, as we now examine. 


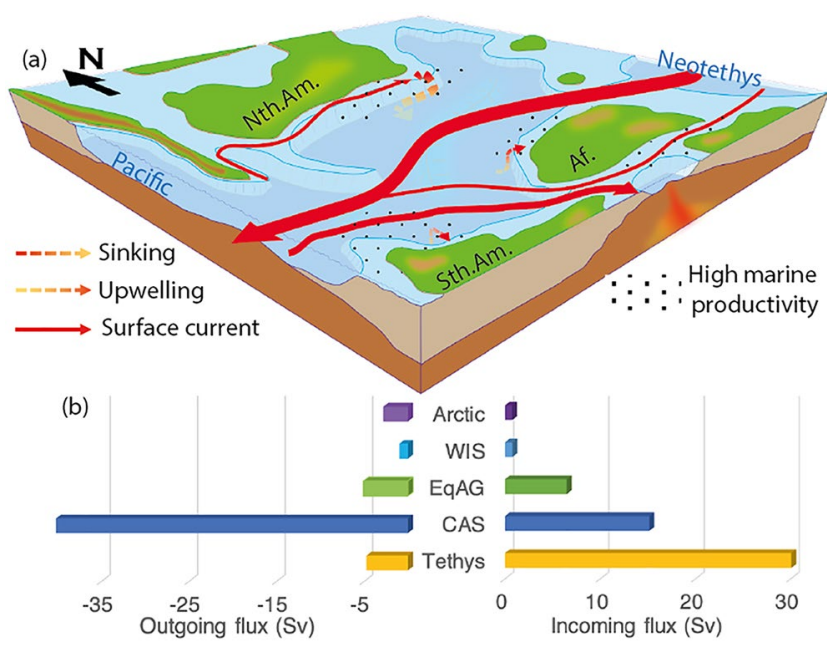

Figure 6. (a) Schematic representation of surface circulation in the Central Atlantic. See localization on Figure 1. Nth.Am.: North America, Sth.Am.: South America, Af.: Africa. (b) Incoming and outgoing fluxes (Sverdrups-Sv) into the Central Atlantic, computed through sections described in Figure 1. The budget is calculated for the DeepCAS simulation, values for IntermediateCAS and ShallowCAS simulations are very similar. Detailed fluxes are shown in Supplementary Data.

\subsection{Central Atlantic Circulation}

We now focus on the Central Atlantic circulation and distinguish three depth intervals: upper ocean circulation ( $<600 \mathrm{~m}$ of water depth), intermediate circulation (600-1,600 $\mathrm{m}$ of water depth) and deep circulation ( $>1,600$ of water depth). Inflow and outflow water fluxes are computed along the five gateways surrounding the Central Atlantic Ocean: the CAS, the EqAG, the WIS, the EGS, and the Tethys Seaway (Figure 1).

\subsubsection{Upper Ocean Circulation (0-600 m)}

Figure 6 depicts the upper ocean circulation of the Central Atlantic, showing the directions of major currents in and out of the Central Atlantic (Figure 6a) and the corresponding water fluxes (Figure 6b). Most of the horizontal circulation is dominated by a westward current, the circum-equatorial current, flowing through the Central Atlantic from the Tethys Seaway (main inflow) to the CAS (main outflow). Similar patterns of upper ocean circulation were simulated in previous modeling studies (Donnadieu et al., 2016; Topper et al., 2011; Trabucho Alexandre et al., 2010). Minor counter-currents also flow into the Central Atlantic across the CAS and the EqAG. The circum-equatorial upper ocean current separates the basin into two distinct areas: an upwelling area in the southern Central Atlantic, strongly influenced by underlying older waters, and a downwelling area in the northern Central Atlantic, in which the thermocline deepens with mixed layer depth reaching $350 \mathrm{~m}$. High marine productivity is simulated in these areas of strong water mixing regardless of the CAS configuration (See Figure S6). In contrast, though the upper ocean circulation is very similar, the intensity of water fluxes through the CAS is smaller for the ShallowCAS simulation, due to the reduced water depth (Figure 6b). Incoming and outgoing fluxes are approximatively halved in the Shallow$C A S$ simulation compared to the Intermediate $C A S$ and DeepCAS simulations.

\subsubsection{Intermediate Circulation (600-1,600 m)}

The intermediate currents system in the Central Atlantic is similar in the DeepCAS and IntermediateCAS simulations (Figures $7 \mathrm{a}$ and $7 \mathrm{c}$ ). The largest incoming water flux comes from the Pacific through the CAS in the deeper intermediate layers. This estuarine circulation between the Pacific and the Central Atlantic is comparable to that suggested by previous model studies (Donnadieu et al., 2016; Monteiro et al., 2012; Topper et al., 2011; Trabucho Alexandre et al., 2010) and explains the latitudinal gradient in water mass properties in the Central Atlantic (Figure S7). The southern part of the basin is under the influence of both intermediate waters coming from the eastern Equatorial Pacific and upwelled waters from the deep Central Atlantic (Figure 7 and Figure S7). As a result, the intermediate southern Central Atlantic is bathed by colder, fresher, and older waters than in the northern Central Atlantic, whose intermediate water mass composition includes a greater proportion of warmer, saltier and younger waters originating from the Neotethys and from sinking waters (Figure S7).

On the contrary, the ShallowCAS simulation exhibits a different intermediate circulation (Figures $7 \mathrm{~b}$ and 7d) because the depth of the CAS prevents intermediate currents to flow across it. The inflow water transport from the Neotethys more than doubles compared to the DeepCAS and IntermediateCAS, and intermediate waters originating from the EqAG start flowing into the Central Atlantic. Without the influence of Pacific intermediate and deep waters, Central Atlantic intermediate waters are then on average younger and warmer in the ShallowCAS simulation than they are in the two other simulations (Figure S7).

\subsubsection{Deep Circulation ( $>1,600 \mathrm{~m})$}

The deep circulation is different for the three CAS configurations (Figure 8). The DeepCAS and IntermediateCAS simulations exhibit water exchange only through the CAS because the depth of the other gateways is less than 1,600 m. The deep Central Atlantic is thus bathed by deep and cold waters from the Pacific. The IntermediateCAS configuration (2,500 $\mathrm{m}$ depth maximum) limits inflows and outflows compared to that of 


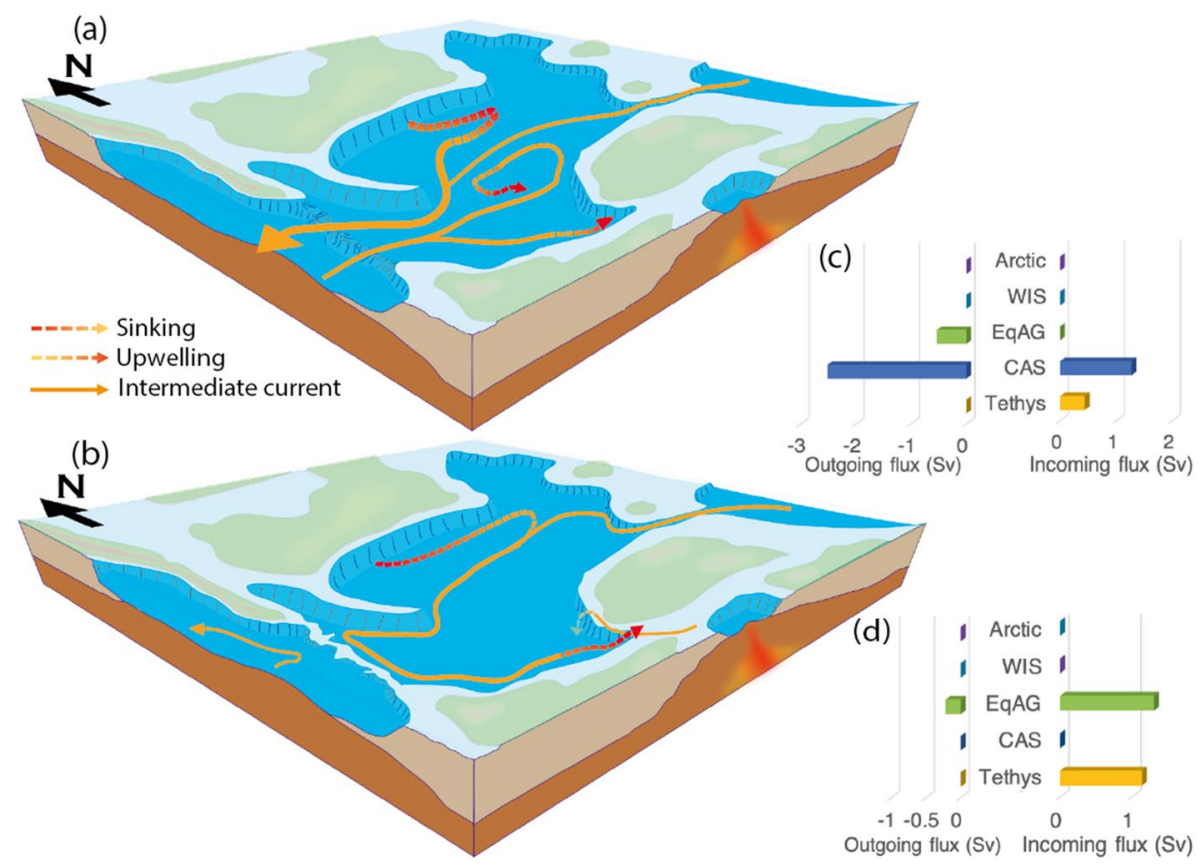

Figure 7. Schematic representation of intermediate circulation in the Central Atlantic for (a) DeepCAS and IntermediateCAS simulations and (b) ShallowCAS simulation. (c) Incoming/outgoing water fluxes (Sverdrups-Sv) for DeepCAS simulation. Fluxes for IntermediateCAS simulations are similar and shown in Supplementary Data. (d) Incoming/outgoing water fluxes for ShallowCAS simulation.

the DeepCAS simulation, and prevents the deepest waters (below 2,500 m) of the Pacific from entering the Central Atlantic. In contrast, in the ShallowCAS configuration, each gateway enclosing the Central Atlantic is closed to deep circulation. The deep Central Atlantic is instead supplied with waters from intermediate levels. In particular, warm intermediate waters coming from the EqAG represent a significant contribution to deep Central Atlantic waters, as indicated by the water density (Figure 9). As a consequence, the deep

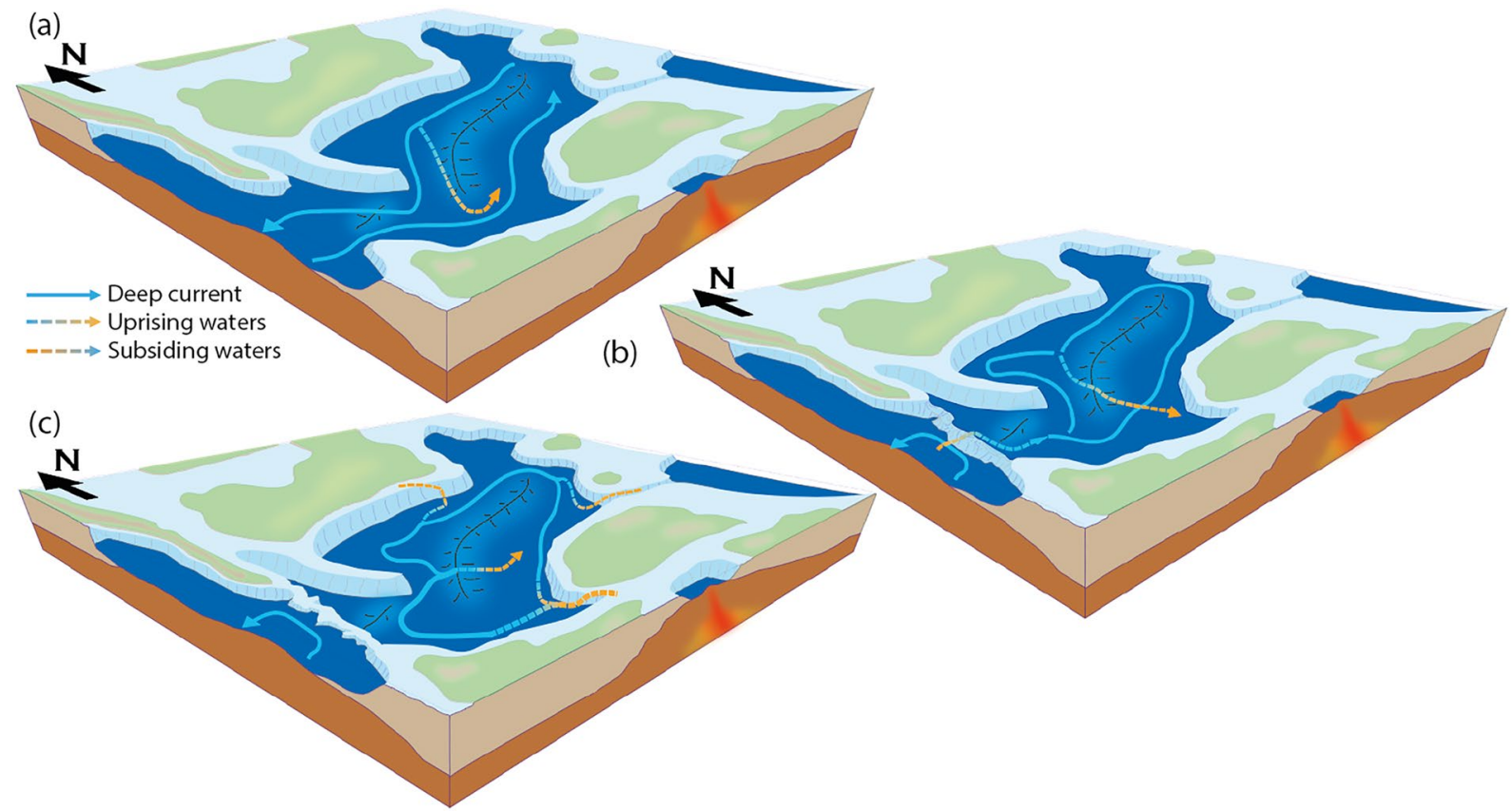

Figure 8. Schematic representation of deep circulation in the Central Atlantic for (a) DeepCAS, (b) IntermediateCAS and (c) ShallowCAS simulations. 


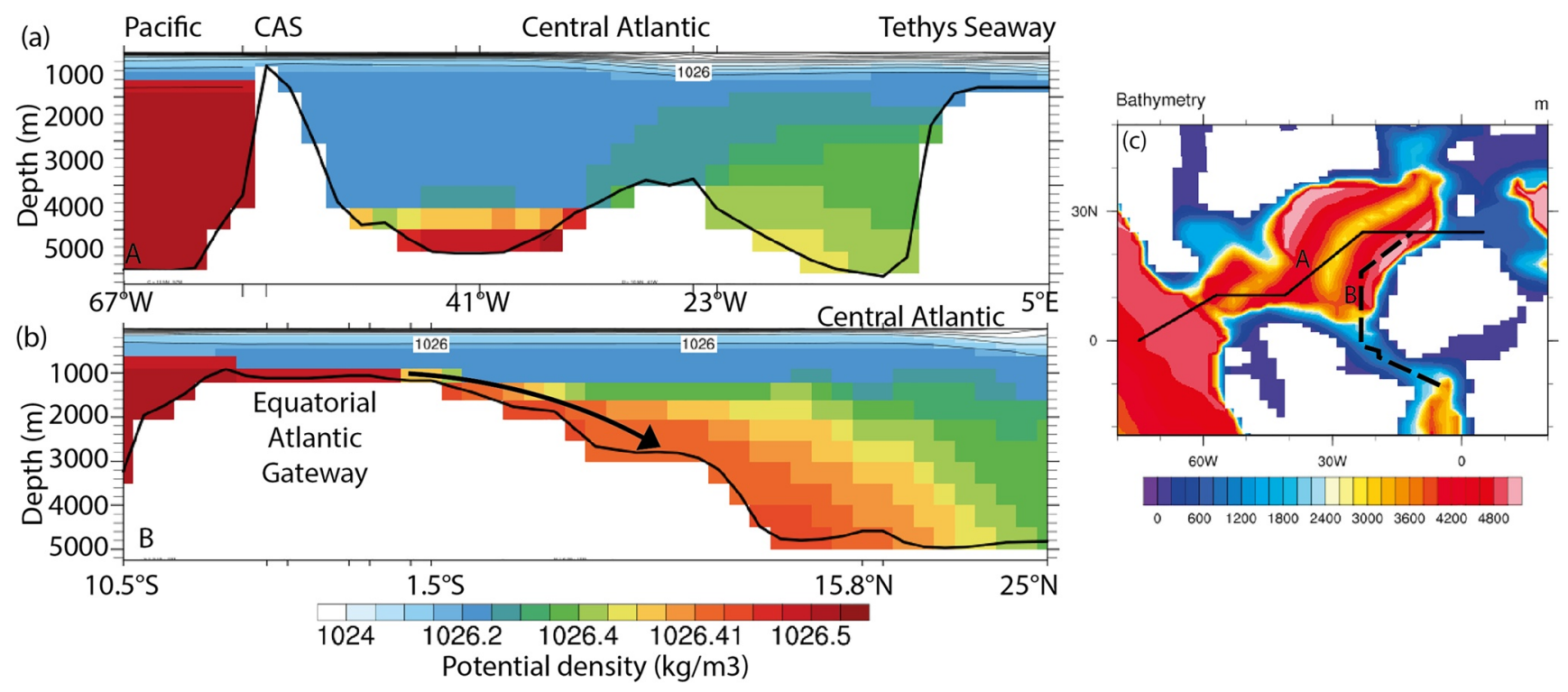

Figure 9. Vertical sections of the water potential density for the ShallowCAS simulation. (a) Section A through the Tethys seaway and (b) section B through the Equatorial Atlantic Gateway (EqAG). Black arrow North of the EqAG (section B) indicates intermediate water subsidence from the EqAG to the Central Atlantic. No subsidence is observed near the Tethys Seaway. (c) Location of the two vertical profiles on the bathymetric map.

Central Atlantic presents much warmer waters compared to the two previous simulations $\left(13.6^{\circ} \mathrm{C}\right.$ vs. $8.7^{\circ} \mathrm{C}$ and $9^{\circ} \mathrm{C}$ for DeepCAS and IntermediateCAS simulations, respectively).

\subsection{Central Atlantic Oxygenation}

The changes in ocean circulation with CAS configuration in the Central Atlantic leads to different oxygenation states at the seafloor (Figure 10). Regions of intermediate and deep depths present a decreasing oxygen content with the shallowing of the CAS. They evolve from a dysoxic or oxic state in the DeepCAS simulation, to an anoxic or dysoxic state in the IntermediateCAS simulation and to complete anoxia in the ShallowCAS simulation. This oxygen-depletion trend is directly linked to the origin of waters bathing the intermediate and deep parts of the basin (Figure 10 and Figure S8). With a deep CAS, the Central Atlantic is supplied with cold and well-oxygenated deep waters from the Pacific. With an intermediate CAS, the Central Atlantic is supplied with less cold and dysoxic intermediate waters from the Pacific, leading to the loss of 1 petamole of oxygen in the Central Atlantic. Using the classical AOU/O2 $2_{\text {sat }}$ decomposition to analyze changes in $\mathrm{O}_{2}$, we find that $62 \%$ of the $\mathrm{O}_{2}$ decrease is due an increase in AOU while the remaining $38 \%$ is due to a decrease in $\mathrm{O}_{2}$ saturation. This indicates a prominent role of ventilation changes over thermal changes in explaining total $\mathrm{O}_{2}$ changes. Finally, with a shallow CAS, the Central Atlantic is primarily supplied with warm and anoxic shallow waters from the Equatorial Atlantic Gateway. More than 2.2 petamoles of oxygen are lost in the Central Atlantic compared to the DeepCAS simulation, the large majority due to decreased $\mathrm{O}_{2}$ saturation (92\%) with a minor contribution from AOU increase (8\%). The shallow CAS, therefore, can be responsible for complete, basin-wide, marine anoxia despite the existence of an active circulation by promoting inflow of warm equatorial waters from the Equatorial OMZ into the Central Atlantic.

Regarding the impact on organic carbon remineralization, no major changes are observed in the Northern Central Atlantic (Figure S9, profile 4) and remineralization profiles are very similar regardless of the CAS configuration. In ShallowCAS, the fact that remineralization and carbon export profiles remain close to that of DeepCAS is due to the counterbalancing effects of increasing temperature and decreasing oxygen (See Table S2 and Figure S9). In the Southern Central Atlantic (Figure S9, profile 5), slightly different remineralization and carbon export profiles are simulated for DeepCAS and ShallowCAS configurations (See Figures S9a and S9b). In DeepCAS, oxic remineralization occurs at the surface and the development of an anoxic OMZ below $150 \mathrm{~m}$ yields to denitrification instead of oxic remineralization, down to 1,000 $\mathrm{m}$ of water depth. In shallow CAS, oxic remineralization also occurs at the surface, however a strong depletion 

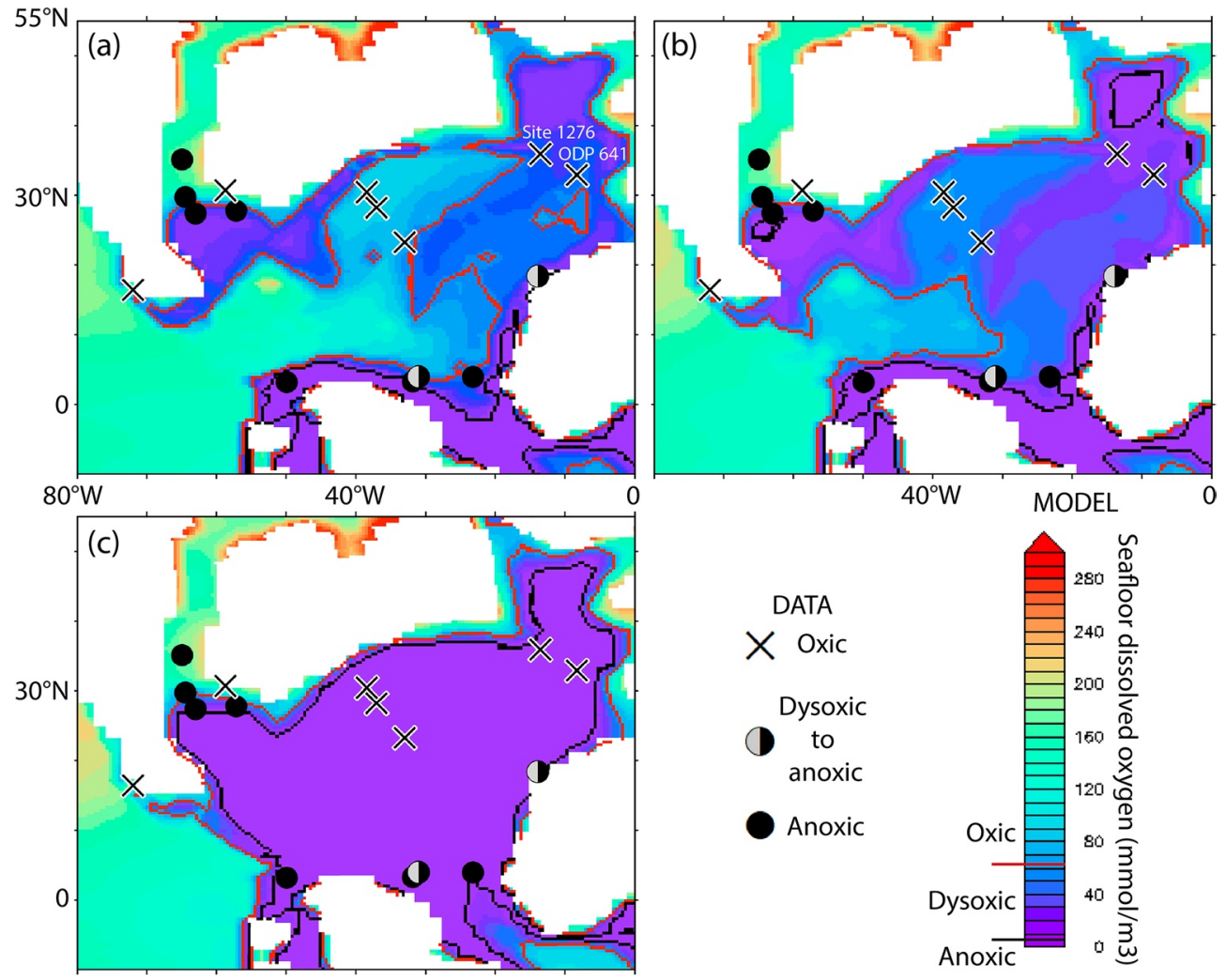

Figure 10. Seafloor dissolved oxygen concentration $\left(\mathrm{mmol} / \mathrm{m}^{3}\right)$ for (a) DeepCAS, (b) IntermediateCAS and (c) ShallowCAS simulations. Red, and black lines correspond to dysoxia and anoxia limits, respectively. Waters are dysoxic for oxygen concentrations below $62.5 \mathrm{mmol} . \mathrm{m}^{-3}$ and anoxic below $6.5 \mathrm{mmol} . \mathrm{m}^{-3}$ (see color scale). Crosses and dots correspond to Pre-Oceanic Anoxic Event 2 redox data (see discussion). Sites IODP 1276 and ODP 641 exhibit a datamodel mismatch addressed in the discussion.

in nitrates down to 2,000 m prevents denitrification in the anoxic OMZ, leading to a slightly higher carbon export than in the DeepCAS, despite higher temperatures. Below 2,000 m, anoxic waters prevent oxic remineralization to occur while a slightly higher concentration in nitrates allows some denitrification.

\section{Discussion}

Our compilation of redox data (See Data D1) indicates the ocean oxygenation state before (Figure 11a) and during OAE2 (Figures 11b-11d), allowing identifying heterogeneous conditions both spatially and temporally. Before OAE2, most of the ocean was oxic, except some areas located in the Central Atlantic (Figure 11a, Southern Central Atlantic, Southern WIS, deepest part of Gulf of Mexico). During OAE2 (Figures 11b-11d), redox data indicates an expansion of the anoxia to the whole Central Atlantic, with some locations showing fluctuations from oxic to dysoxic/anoxic conditions (e.g., in the WIS, Northern Central Atlantic, Moroccan margin). Outside the Central Atlantic, the dysoxia/anoxia extends to the Southern Atlantic and to the Neotethys (deep outer shelves or even some parts of the deep basin), with fluctuations between oxic and anoxic conditions also reconstructed in some locations. In the easternmost part of the South Neotethys (e.g., North Indian, Kerguelen plateau) as well as in the Northern Pacific coasts, dysoxia is sometimes reached during OAE2, but in alternation with oxic conditions. Finally, the Southern Pacific always stays oxic.

In the following, we compare our modeling results to these oxygenation trends for the pre-OAE and OAE2 periods, in a first step at the global scale, and in a second step with a focus on the Central Atlantic, in order to investigate the question of the CAS paleobathymetry. 

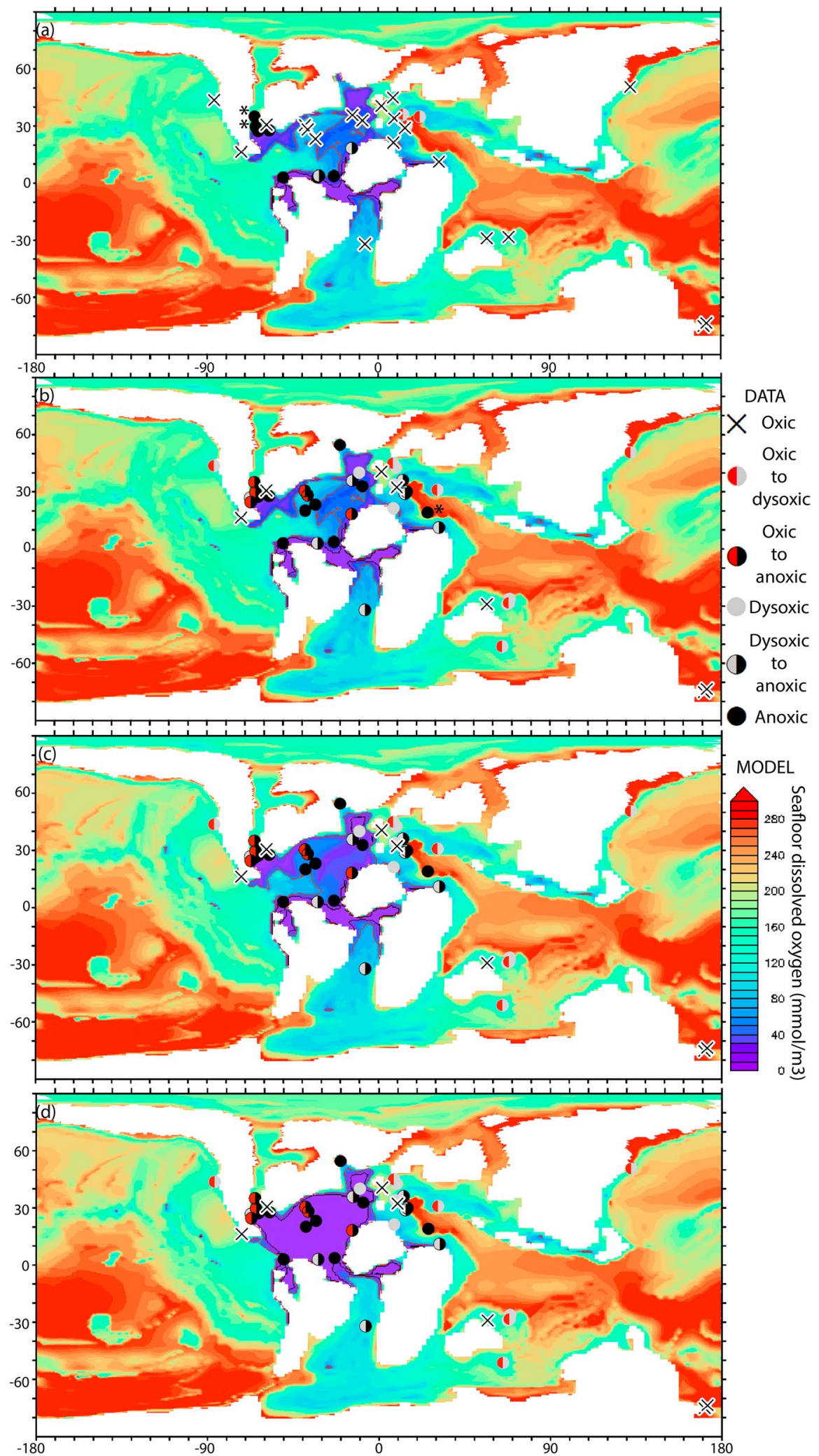

Figure 11. Simulated seafloor dissolved oxygen concentration compared with redox data for (a) the pre-Oceanic Anoxic Event 2 (OAE2) period and (b) the OAE2 for the DeepCAS simulation, (c) the OAE2 for the IntermediateCAS simulation and (d) the OAE2 and the ShallowCAS simulation. The black and red lines indicate the limits of anoxia and dysoxia, respectively. Dots emphasized with asterisks correspond to model-data mismatches discussed. 


\subsection{The Pre-OAE2 Oxygenation State: A Data/Model Comparison}

Outside the Central Atlantic, the results predicted by our three Cenomanian simulations agree well with reconstructions of oceanic oxygen state inferred from data for pre-OAE2, as illustrated in the DeepCAS simulation (Figure 11a). Most of the sites suggest sedimentary burial in oxic conditions and the model consistently reproduces a well-oxygenated seafloor at the site locations. Simulated dissolved oxygen concentrations show that these oxic environments exhibit a large range of values, from $62.5 \mathrm{mmol} / \mathrm{m}^{3}$ (dysoxia limit) to more than $300 \mathrm{mmol} / \mathrm{m}^{3}$ but, unfortunately, proxies only discriminate anoxic/dysoxic from oxic conditions and rarely allow to reconstruct the absolute oxygen concentration in oxic environments. However, it is interesting that all sites that shift from an oxic to a dysoxic or anoxic environment during OAE2 (Figure 11b) are located in areas where the model simulates moderate oxygenation for the pre-OAE2 (e.g., Southern Atlantic, Tethyan continental slopes, North-Eastern Africa, $\left[\mathrm{O}_{2}\right] \sim<120 \mathrm{mmol} / \mathrm{m}^{3}$ ) driven by ba$\sin$ restriction and/or reduced $\mathrm{O}_{2}$ saturation due to elevated temperatures. Other sites that remain oxic or dysoxic during OAE2 are found in more-oxygenated areas during pre-OAE2 (North-Eastern/North-Western-Central Pacific, shallow Tethyan and Tibetan platforms, Kerguelen plateau, $\left.\left[\mathrm{O}_{2}\right]>150 \mathrm{mmol} / \mathrm{m}^{3}\right)$. Finally, the New Zealand site is interesting in that neither the model nor proxy records document any major change in oxygen concentrations during OAE2, which agrees with the site location in an area of deep-water formation ensuring high simulated oxygen values (New-Zealand, $\left[\mathrm{O}_{2}\right] \sim>250 \mathrm{mmol} / \mathrm{m} 3$ ). One site in the Neotethys does not follow this trend with data documenting anoxic conditions at the location of which the model simulates elevated oxygen concentrations (Figure 11b). This inconsistency could be due to the complex paleogeography of the western Neotethys that is compartmented in numerous restricted deep basins separated by shallow platforms (Golonka et al., 2000; Nouri et al., 2016). Anoxia could locally exist in such basins but this degree of complexity is not represented at the spatial resolution of our model.

Seafloor oxygen concentrations in the Central Atlantic basin are, in contrast, highly sensitive to the configuration of the CAS and a specific comparison to data is made in Section 4.3 for the Central Atlantic. For areas where the oxygen level is relatively insensitive to CAS depths, that is, the southern Central Atlantic and the northern Gulf of Mexico, the model reproduces the dysoxic and anoxic areas inferred from proxy data for the pre-OAE2 interval (Figures 10 and 11a). Finally, the WIS represents another location of model-data mismatch in the three simulations because the model suggests oxygenated conditions at odds with observations of anoxia at this site ( 2 dots, see Figure 11a). However, the oxygenation state has been shown to be related to sea-level variations in this region (Lowery, Cunningham, et al., 2017; Lowery, Leckie, et al., 2017), which are not taken into account in the simulations and may provide an explanation to the model/data discrepancy.

At the global scale, the spatial patterns of simulated seafloor oxygen are consistent with the modeling study of Monteiro et al. (2012) that uses the GENIE EMIC. Their experimental set-up employs a similar paleogeography as in this study, with two different CAS configurations (1,500 and 3,000 m, which broadly correspond to our intermediate and deep CAS configurations, respectively). The nutrient oceanic budget in Monteiro et al. (2012) is equal to the modern one as in our simulations but a pre-industrial $p \mathrm{CO}_{2}$ is used whereas we prescribe four times the pre-industrial value. The most severe anoxic regions are the Central/Equatorial Atlantic and dysoxia is simulated in the Neotethys and Eastern Pacific oceans whereas the Southern Pacific remains more oxygenated. The seafloor is however globally less oxygenated in Monteiro et al. (2012), likely due to a less intense overturning circulation (around $6 \mathrm{~Sv}$ in the intermediate ocean vs. $18 \mathrm{~Sv}$ in our study). Another major difference is observed in the South Atlantic where the model of Monteiro et al. (2012) simulates higher oxygen concentrations, probably due to deep-water formation in this area, which is absent in our model. This inconsistency is hard to resolve at the moment as there is no data available in this region for the Cenomanian. From a physical perspective, Donnadieu et al. (2016) also suggested weak deep-water formation in the South Atlantic using the coarse-resolution FOAM global climate model. On the contrary, the more complex CCSM4 ESM Cenomanian simulation of Ladant et al. (2020) does not produce deep-water formation in the South Atlantic, indicating that these inconsistencies could be a problem of model complexity and resolution, and/or employed paleogeography.

Our results illustrate a long-term control of paleogeography on oceanic oxygen beyond OAE2 shorter-term triggers. For example, the anoxia located in the Southern Central and Equatorial Atlantic is a robust feature of our and previous simulations (Monteiro et al., 2012) under pre-OAE2 conditions and is also inferred from pre-OAE2 data, suggesting that this localized anoxia is driven by paleogeography and is decoupled from 
the specific triggers of the OAE2. In addition, regions where anoxia spreads over during OAE2 were those already characterized by reduced oxygenation in our model. Our results therefore suggest a significant preconditioning of the global ocean oxygenation on the runup to the OAE2 driven by paleogeographic setting of the Cenomanian. More generally, we can hypothesize that ocean preconditioning is required for OAEs to occur (See also Song et al., 2019) and that shorter-term controllers (such as an abrupt rise of $p \mathrm{CO}_{2}$ or an increase in nutrient supply) would then turn preconditioned areas into dysoxic or anoxic environments (See also Dummann, Steinig, Hofmann, Lenz, et al., 2020).

\subsection{Constraining Oceanic Gateways Paleobathymetry}

The CLIP is estimated to have mainly formed between 95 and $83 \mathrm{Ma}$ in the Pacific Ocean westward of the CAS and to have moved through the CAS during the Late Cretaceous (Andjić et al., 2019; Dürkefälden et al., 2019; Loewen et al., 2013; Romito \& Mann, 2020), thereby shallowing the connection between the Central Atlantic and Pacific oceans (Buchs et al., 2018). Numerous evidence suggest a significant role for the CLIP volcanism in the initiation of OAE2 (Joo et al., 2020; Kerr \& Kerr, 1998; Turgeon \& Creaser, 2008). However, the timing of its formation and progressive eastward movement is not well constrained. This complexity limits inferences about the potential contribution of a CLIP-induced shallowing of the CAS to OAE2. In an attempt to better constrain the CAS paleobathymetry during the Late Cenomanian, we compare the study sites of the Central Atlantic to our three scenarios of seafloor oxygen simulated for the different CAS configurations (Deep, Intermediate, Shallow; Figure 10).

Seven sites document anoxic conditions before OAE2. They are located in the Southern Central Atlantic and in the Gulf of Mexico (Figure 10; Kuypers et al., 2002; Lowery, Cunningham, et al., 2017; Lowery, Leckie, et al., 2017; Owens et al., 2012; Perez-Infante et al., 1996; van Helmond, Ruvalcaba Baroni, et al., 2014; Westermann et al., 2014). In particular, previous studies suggested that the anoxic area surrounding the Equatorial Atlantic Gateway was driven by the estuarine circulation established between the Pacific and Central Atlantic (Topper et al., 2011; Trabucho Alexandre et al., 2010) but our results demonstrate that this anoxic area is stable even in the ShallowCAS simulation despite the disappearance of the estuarine circulation. Our findings imply that this anoxic zone would rather be driven by the global paleogeography than regionally controlled by the CAS. In fact, all these pre-OAE2 anoxic sites are located in regions simulated as dysoxic to anoxic regardless of the CAS configuration and, thus, a comparison between our simulations does not help constraining the CAS depth.

In the deep Central Atlantic, five sites record oxic conditions before OAE2 (Figure 10; Owens et al., 2012; van Helmond, Ruvalcaba Baroni, et al., 2014). The comparison with modeling results is partially consistent only for the DeepCAS simulation (Figure 10a). In this scenario, the deep connection (>2,500 m depth) between the Pacific and Central Atlantic basins allows oxygenated deep waters from the Pacific to flow into and fill the western part of the deep Central Atlantic (Figure S8), resulting in simulated oxic deep waters that correlate with the proxy record. In the IntermediateCAS simulation, the shallower CAS $(<2,500 \mathrm{~m}$ of water depth) prevents these oxygenated deep waters to penetrate into the Central Atlantic, which is supplied by oxygen-poor intermediate waters resulting in dysoxic conditions, which is not consistent with data in the deep Central Atlantic for the pre-OAE2 (Figure 10b). The same conclusion is made for the Shallow$C A S$ scenario, for which the deep Central Atlantic is fully anoxic due to very high sea-bottom temperature and subsidence of anoxic waters from the Equatorial Atlantic Gateway (Figure 10c).

In contrast to the western part, the eastern part of the Central Atlantic remains dysoxic to anoxic in the deep, regardless of the CAS depth, probably because of the combination of its bottleneck configuration for deep circulation and of elevated marine productivity above (Figure S6). These reduced oxygen conditions are inconsistent with pre-OAE2 data for the eastern Central Atlantic that document oxic environments (van Helmond, Ruvalcaba Baroni, et al., 2014). This discrepancy suggests that an intermittent source of oxygenated deep waters may have existed in the northern part of the Cenomanian Central Atlantic, thereby creating oxic conditions in the deep eastern side of the basin (Figure 10; Sites 1276 and 641) prior to the OAE2. The recent Cenomanian simulation of Ladant et al. (2020) indicate possible deep-water formation in the Cenomanian North Atlantic but this source does not exist in our simulations, and we note that evidence is lacking to unambiguously confirm its existence. A deeper connection with the Neotethys is also suggested during the Late Cretaceous (Buchs et al., 2018; Nouri et al., 2016) and could supply oxygen to 
the North-Eastern Central Atlantic. However, reconstructing paleogeography and paleobathymetry in this area is particularly challenging because the Neotethyan region is composed of numerous shallow carbonate platforms separated by deep and narrow corridors (Stampfli \& Borel, 2002). As such, we cannot draw from our results anything but speculative conclusions about a possible role of the Tethys Seaway on the evolution of deep Central Atlantic oxygenation.

Our numerical results and the absence of anoxia in the Cenomanian Central Atlantic basin prior to the OAE2 thus suggest that deep connections existed between this basin and the Pacific before the OAE2 in order to fill the Central Atlantic with well-oxygenated deep waters. This result suggests either that the CLIP entered the CAS, at the earliest, close to the beginning of the OAE2, or that multiple volcanic arc systems separated by deep channels were in place around the CLIP (Romito \& Mann, 2020). A tantalizing implication of our results is that the early eastward movement of the CLIP across the CAS at the end of the Cenomanian may have participated in or controlled the formation of a complete anoxia in the deep Central Atlantic during the OAE2. A CLIP-driven full anoxia as simulated in the ShallowCAS simulation however implies the existence of a mechanism providing a way out of the anoxia because the OAE2 remains a transient perturbation. Its duration $(=<1 \mathrm{Ma})$ is indeed incompatible with the timespan of the CLIP presence in the CAS if we consider that the CLIP entered the CAS at the beginning of the OAE2. The aforementioned development of deep channels in the Tethys Seaway or intermittent deep-water formation are plausible but elusive possibilities. Alternatively, biogeochemical feedbacks may provide another mechanism. Indeed, severe anoxia leading to high rates of organic matter burial and denitrification may slowly deplete the Central Atlantic of its nutrients, in which case productivity would decrease and oxygenation increase again. As a simple test, we branch another offline PISCES simulation exactly similar to the ShallowCAS except that we turn off the restoring of nutrients. Coherent with this hypothesis, the nitrate budget decreases in the Central Atlantic because of intense denitrification, which drives a slight decrease of marine productivity and reoxygenation ( $+24 \mathrm{Tmol} / 3,500$ years). Extrapolating the rate of change, it would take $\sim 320,000$ years to return to the same oxygen budget as in the DeepCAS simulation, which in principle is concordant with the OAE2 timescale and transient nature. However, this picture does not take into account the coeval increase in nutrient inputs from increased weathering due to volcanism or higher atmospheric $\mathrm{CO}_{2}$ during the perturbation (Adams et al., 2010; Barclay et al., 2010; Joo et al., 2020; Pogge Von Strandmann et al., 2013; Turgeon \& Creaser, 2008) nor sedimentary feedbacks such as phosphorus remobilization in anoxic bottom waters (e.g., Palastanga et al., 2011), which may counterbalance nutrient depletion and promote anoxia.

\subsection{Wider Implications From Other Regions}

Despite its potential contribution or control on Central Atlantic anoxia during the OAE2, the CLIP-driven shallowing of the CAS cannot be the only triggering factor for the OAE2 because the expansion of seafloor anoxia precisely remains limited to the North Atlantic whereas inferences from the data suggest a more global expansion (Figure 11). The proportion of anoxic/dysoxic seafloor at the global scale in our simulations is of 5\% of the total seafloor area in DeepCAS, 4\% in IntermediateCAS and 7\% in ShallowCAS. The transition from a deep to shallow CAS in our simulations may explain the $40 \%$ increase of dysoxia/anoxia suggested during OAE2 (Ostrander et al., 2017) but does not explain the spatial distribution of redox indicators during OAE2 (Figure 11). Moreover, the simulated proportion of sea floor anoxia in our simulations does not agree with previous estimates, suggesting that 8\%-15\% (Clarkson et al., 2018) or even up to 50\% (Monteiro et al., 2012) of the global seafloor becomes anoxic, including up to $10 \%$ of euxinic areas waters (Dickson, 2017; Owens et al., 2013).

In light of the above considerations and of the current knowledge of the Cenomanian paleogeography and CLIP history, our results support a main driver for the OAE2 with global implications, such as increased inputs of weathered material (e.g., Pogge Von Strandmann et al., 2013), with a plausible role for the CAS bathymetric evolution. However, our simulations cannot unambiguously rule out other hypotheses mentioned above, such as changes in the bathymetry of the Tethys Seaway. Numerous supplementary simulations are necessary to disentangle the role of each forcing and feedback, which we leave for future work. 


\subsection{How to Make an Ocean Anoxic Despite an Active Circulation?}

Conceptually, basin-scale anoxia is often thought in terms of very weak renewal of deep-water masses. Silled basins are a prime example as they are affected by a strong circulation restriction and stratification with long water renewal rate (Algeo \& Lyons, 2006). It was for instance calculated that the renewal rate in the anoxic Cleveland basin during the Toarcian Oceanic Anoxic Event was between 4,000 and 40,000 years (McArthur et al., 2008). During the OAE2, the renewal rate in the deep Central Atlantic is estimated between 500 and 4,000 years (van Helmond, Ruvalcaba Baroni, et al., 2014), which is similar to that of the modern Black Sea (Algeo \& Lyons, 2006). This estimation is consistent with the three simulated scenarios that exhibit water ages in the deep Central Atlantic comprised between $\sim 500$ years (in the ShallowCAS simulation) and 2,000 years (in the IntermediateCAS simulation). The ShallowCAS scenario provides interesting insights in terms of ocean dynamics and oxygenation mechanisms by showing that the degree of oxygen depletion can be linked to the provenance of water masses rather than a sluggish circulation. Indeed, this silled basin in the ShallowCAS simulation exhibits an active deep circulation (around 5-6 Sv), with relatively short renewal age, and is fully anoxic at the same time because incoming subsiding waters that flow into the deep Central Atlantic come from the anoxic OMZ of the Equatorial Atlantic Gateway. These results propose an alternative to the common view that ocean stagnation is required to create anoxia and enhance organic carbon burial in deep basins.

Previous model studies have also suggested that ocean stagnation was not sufficient to create intermediate to shallow anoxia/euxinia (Monteiro et al., 2012; Ozaki et al., 2011). (Ozaki et al., 2011) showed that ocean stagnation only promoted deep-water anoxia and that massive phosphorus inputs were additionally required to create a global anoxia by enhancement of marine productivity. Monteiro et al. (2012) observed as well that enhanced marine productivity due to higher nutrient content was the most efficient process to expand oceanic anoxia. Our findings demonstrate that full basin-scale anoxia can co-exist with an active ocean circulation and without the need for enhanced productivity.

\section{Conclusion}

The activity of the CLIP in the Late Cenomanian have impacted the paleobathymetry of the CAS via the formation of the Caribbean plateau. In this study, we use the IPSLCM5A2 earth system model, which includes the marine biogeochemistry model PISCES, to explore the impact of the paleobathymetry of the CAS on oceanic circulation and dissolved oxygen distribution during the Cenomanian. Regardless of the depth of the CAS, the model simulates an active oceanic circulation, dominated by influx from the Pacific Ocean. The spatial variations of the global oxygen distribution compare well with pre-OAE2 proxy records and exhibit oceanic environments ranging from fully oxic to fully anoxic. These spatial variations are strongly driven by the global paleobathymetry and by the configuration of oceanic gateways that control the pathways of deep currents and the associated oxygen supply. Restricted basins such as the Central and South Atlantic are oxygen-poor and even locally anoxic in all simulations, while the deep Southern Pacific is well-oxygenated because it is a region of deep-water formation. The depth of the CAS, however, exerts substantial control on the seafloor oxygen concentration of the Central Atlantic basin. In the DeepCAS configuration, most of the deep western Central Atlantic is oxic whereas the deep eastern part of the basin is dysoxic. Dysoxia spreads westward in the IntermediateCAS configuration while a complete anoxia develops in the whole basin in the ShallowCAS configuration. A comparison with redox proxy data suggests that a deep connection $(>2,500 \mathrm{~m})$ existed before the OAE2 between the Pacific and Central Atlantic. A shallowing of the CAS to a shallower depth ( 2,500 m of water depth or less) due to the eastward movement of the Caribbean LIP may have participated in the establishment of complete dysoxic to anoxic environments in the deep Central Atlantic, by reducing the oxygen supply from Pacific bottom waters, but does not constitute the main triggering factor of OAE2. These results illustrate how long-term paleobathymetric forcings may precondition the ocean for favorable low-oxygen conditions allowing OAEs to develop and high quantity of organic carbon to be preserved in the oceans and eventually buried. 


\section{Data Availability Statement}

LMDZ, XIOS, NEMO, and ORCHIDEE are released under the terms of the CeCILL license. OASIS-MCT is released under the terms of the Lesser GNU General Public License (LGPL). IPSL-CM5A2 code is publicly available through svn, with the following command lines: svn co http://forge.ipsl.jussieu.fr/igcmg/svn/ modipsl/branches/publications/IPSLCM5A2.1_11192019modipslcdmodipsl/util;./modelIPSLCM5A2.1 The mod.def file provides information regarding the different revisions used, namely: NEMOGCM branch nemo_v3_6_STABLE revision 6665, XIOS2 branchs/xios-2.5 revision 1763, IOIPSL/src svn tags/v2_2_2, LMDZ5 branches/IPSLCM5A2.1 rev 3591, branches/publications/ORCHIDEE_IPSLCM5A2.1.r5307 rev 6336, OASIS3-MCT 2.0_branch (rev 4775 IPSL server). The login/password combination requested at first use to download the ORCHIDEE component is anonymous/anonymous. We recommend to refer to the project website: http://forge.ipsl.jussieu.fr/igcmg_doc/wiki/Doc/Config/IPSLCM5A2 for a proper installation and compilation of the environment. Model outputs used to generate the figures shown in the paper are available in open access at https://doi.org/10.5281/zenodo.4915874, as well as data tables for (a) water flux details and (b) the compilation of Cenomanian-Turonian redox data from previous publications.

\section{Acknowledgments}

We express our thanks to Total E\&P for funding the project and granting permission to publish. We acknowledge Olivier Aumont for its contribution to the development of the adapted version of the PISCES code for deep-time simulations. We thank the CEA/CCRT for providing access to the HPC resources of TGCC under the allocation 2017A0010102212, 2018-A0030102212, and 2019-A0050102212 made by GENCI. We acknowledge the use of Ferret (http:// ferret.pmel.noaa.gov/Ferret/), NCL and ArcGIS softwares for analysis and figures in this paper.

\section{References}

Adams, D. D., Hurtgen, M. T., \& Sageman, B. B. (2010). Volcanic triggering of a biogeochemical cascade during Oceanic Anoxic Event 2. Nature Geoscience, 3(3), 201-204. https://doi.org/10.1038/ngeo743

Algeo, T. J., \& Lyons, T. W. (2006). Mo-total organic carbon covariation in modern anoxic marine environments: Implications for analysis of paleoredox and paleohydrographic conditions. Paleoceanography, 21(1). https://doi.org/10.1029/2004PA001112

Andjić, G., Baumgartner, P. O., \& Baumgartner-Mora, C. (2019). Collision of the Caribbean Large Igneous Province with the Americas: Earliest evidence from the forearc of Costa Rica. Bulletin of the Geological Society of America, 131(9-10), 1555-1580. https://doi. $\operatorname{org} / 10.1130 /$ B35037.1

Arthur, M. A., Schlanger, S. O., \& Jenkyns, H. C. (1987). The Cenomanian-Turonian Oceanic Anoxic Event, II. Paleoceanographic controls on organic-matter production and preservation. Geological Society, London, Special Publications, 26, 401-420. https://doi.org/10.1144/ gsl.sp.1987.026.01.25

Aumont, O., Ethé, C., Tagliabue, A., Bopp, L., \& Gehlen, M. (2015). PISCES-v2: An ocean biogeochemical model for carbon and ecosystem studies. Geoscientific Model Development, 8(8), 2465-2513. https://doi.org/10.5194/gmd-8-2465-2015

Barclay, R. S., McElwain, J. C., \& Sageman, B. B. (2010). Carbon sequestration activated by a volcanic CO 2 pulse during Ocean Anoxic Event 2. Nature Geoscience, 3(3), 205-208. https://doi.org/10.1038/ngeo757

Batenburg, S. J., De Vleeschouwer, D., Sprovieri, M., Hilgen, F. J., Gale, A. S., Singer, B. S., et al. (2016). Orbital control on the timing of oceanic anoxia in the Late Cretaceous. Climate of the Past, 12(10), 2009-2016. https://doi.org/10.5194/cp-12-1995-2016

Bice, K. L., Birgel, D., Meyers, P. A., Dahl, K. A., Hinrichs, K. U., \& Norris, R. D. (2006). A multiple proxy and model study of Cretaceous upper ocean temperatures and atmospheric CO2 concentrations. Paleoceanography, 21(2), 1-17. https://doi.org/10.1029/2005PA001203

Blättler, C. L., Jenkyns, H. C., Reynard, L. M., \& Henderson, G. M. (2011). Significant increases in global weathering during Oceanic Anoxic Events 1a and 2 indicated by calcium isotopes. Earth and Planetary Science Letters, 309(1-2), 77-88. https://doi.org/10.1016/j. epsl.2011.06.029

Bopp, L., Resplandy, L., Untersee, A., Le Mezo, P., \& Kageyama, M. (2017). Ocean (de)oxygenation from the Last Glacial Maximum to the twenty-first century: Insights from Earth System models. Philosophical Transactions of the Royal Society A, 375(2102). https://doi. org/10.1098/rsta.2016.0323

Buchs, D. M., Kerr, A. C., Brims, J. C., Zapata-Villada, J. P., Correa-Restrepo, T., \& Rodríguez, G. (2018). Evidence for subaerial development of the Caribbean oceanic plateau in the Late Cretaceous and palaeo-environmental implications. Earth and Planetary Science Letters, 499, 62-73. https://doi.org/10.1016/j.epsl.2018.07.020

Clarkson, M. O., Stirling, C. H., Jenkyns, H. C., Dickson, A. J., Porcelli, D., Moy, C. M., et al. (2018). Uranium isotope evidence for two episodes of deoxygenation during Oceanic Anoxic Event 2. Proceedings of the National Academy of Sciences of the United States of America, 115(12), 2918-2923. https://doi.org/10.1073/pnas.1715278115

Degens, E. T., \& Stoffers, P. (1976). Stratified waters as a key to the past. Nature, 263(5572), 22-27. https://doi.org/10.1038/263022a0

Dickson, A. J. (2017). A molybdenum-isotope perspective on Phanerozoic deoxygenation events. Nature Geoscience, 10(10), 721-726. https://doi.org/10.1038/NGEO3028

Donnadieu, Y., Pierrehumbert, R., Jacob, R., \& Fluteau, F. (2006). Modeling the primary control of paleogeography on Cretaceous climate. Earth and Planetary Science Letters, 248(1-2), 411-422. https://doi.org/10.1016/j.epsl.2006.06.007

Donnadieu, Y., Pucéat, E., Moiroud, M., Guillocheau, F., \& Deconinck, J. F. (2016). A better-ventilated ocean triggered by Late Cretaceous changes in continental configuration. Nature Communications, 7. https://doi.org/10.1038/ncomms10316

Dufresne, J. L., Foujols, M. A., Denvil, S., Caubel, A., Marti, O., Aumont, O., et al. (2013). Climate change projections using the IPSL-CM5 earth system model: From CMIP3 to CMIP5.

Dummann, W., Steinig, S., Hofmann, P., Flögel, S., Osborne, A. H., Frank, M., et al. (2020). The impact of Early Cretaceous gateway evolution on ocean circulation and organic carbon burial in the emerging South Atlantic and Southern Ocean basins. Earth and Planetary Science Letters, 530, 115890. https://doi.org/10.1016/j.epsl.2019.115890

Dummann, W., Steinig, S., Hofmann, P., Lenz, M., Kusch, S., Herrle, J. O., et al. (2020). Driving mechanisms of organic carbon burial in the Early Cretaceous South Atlantic Cape Basin (DSDP Site 361). Climate of the Past, 17.

Dunne, J. P., Sarmiento, J. L., \& Gnanadesikan, A. (2007). A synthesis of global particle export from the surface ocean and cycling through the ocean interior and on the seafloor. Global Biogeochemical Cycles, 21(4), 1-16. https://doi.org/10.1029/2006GB002907

Dürkefälden, A., Hoernle, K., Hauff, F., Wartho, J. A., van den Bogaard, P., \& Werner, R. (2019). Age and geochemistry of the Beata Ridge: Primary formation during the main phase ( $\sim 89 \mathrm{Ma})$ of the Caribbean Large Igneous Province. Lithos, 328-329, 69-87. https://doi.org/10.1016/j.lithos.2018.12.021 
Du Vivier, A. D. C., Selby, D., Sageman, B. B., Jarvis, I., Gröcke, D. R., \& Voigt, S. (2014). Marine187Os/188Os isotope stratigraphy reveals the interaction of volcanism and ocean circulation during Oceanic Anoxic Event 2. Earth and Planetary Science Letters, 389, 23-33. https://doi.org/10.1016/j.epsl.2013.12.024

Eldrett, J. S., Minisini, D., \& Bergman, S. C. (2014). Decoupling of the carbon cycle during ocean anoxic event 2. Geology, 42(7), 567-570. https://doi.org/10.1130/G35520.1

Erbacher, J., Huber, B. T., Norris, R. D., \& Markey, M. (2001). Increased thermohaline stratification as a possible cause for an ocean anoxic event in the cretaceous period. Nature, 409(6818), 325-327. https://doi.org/10.1038/35053041

Fichefet, T., \& Maqueda, M. A. M. (1997). Sensitivity of a global sea ice model to the treatment of ice thermodynamics and dynamics. Journal of Geophysical Research: Ocean, 102(C6), 12609-12646. https://doi.org/10.1029/97JC00480

Flögel, S., Wallmann, K., Poulsen, C. J., Zhou, J., Oschlies, A., Voigt, S., \& Kuhnt, W. (2011). Simulating the biogeochemical effects of volcanic $\mathrm{CO}_{2}$ degassing on the oxygen-state of the deep ocean during the Cenomanian/Turonian Anoxic Event (OAE2). Earth and Planetary Science Letters, 305(3-4), 371-384. https://doi.org/10.1016/j.epsl.2011.03.018

Gangl, S. K., Moy, C. M., Stirling, C. H., Jenkyns, H. C., Crampton, J. S., Clarkson, M. O., et al. (2019). High-resolution records of Oceanic Anoxic Event 2: Insights into the timing, duration and extent of environmental perturbations from the palaeo-South Pacific Ocean. Earth and Planetary Science Letters, 518, 172-182. https://doi.org/10.1016/j.epsl.2019.04.028

Gernigon, L., Franke, D., Geoffroy, L., Schiffer, C., Foulger, G. R., \& Stoker, M. (2020). Crustal fragmentation, magmatism, and the diachronous opening of the Norwegian-Greenland Sea. Earth-Science Reviews, 206. https://doi.org/10.1016/j.earscirev.2019.04.011

Golonka, J., Oszczypko, N., \& Ślączka, A. (2000). Late Carboniferous Neogene geodynamic evolution and paleogeography of the circum-Carpathian region and adjacent areas. Annales Societatis Geologorum Poloniae, 70, 107-136.

Gough. (1981). Solar interior structure variations*. Solar Physics, 74(September 1980), 21-34.

Hourdin, F., Foujols, M. A., Codron, F., Guemas, V., Dufresne, J. L., Bony, S., et al. (2013). Impact of the LMDZ atmospheric grid configuration on the climate and sensitivity of the IPSL-CM5A coupled model. Climate Dynamics, 40(9-10), 2167-2192. https://doi.org/10.1007/ s00382-012-1411-3

Jenkyns, H. C. (2010). Geochemistry of oceanic anoxic events. Geochemistry, Geophysics, Geosystems, 11(3), 1-30. https://doi. org/10.1029/2009GC002788

Jenkyns, H. C., Dickson, A. J., Ruhl, M., \& van den Boorn, S. H. J. M. (2017). Basalt-seawater interaction, the Plenus Cold Event, enhanced weathering and geochemical change: Deconstructing Oceanic Anoxic Event 2 (Cenomanian-Turonian, Late Cretaceous). Sedimentology, 64(1), 16-43. https://doi.org/10.1111/sed.12305

Jones, M. M., Sageman, B. B., Oakes, R. L., Parker, A. L., Leckie, R. M., Bralower, T. J., et al. (2019). Astronomical pacing of relative sea level during Oceanic Anoxic Event 2: Preliminary studies of the expanded SH\#1 Core, Utah, USA. Bulletin of the Geological Society of America, 131(9-10), 1702-1722. https://doi.org/10.1130/B32057.1

Joo, Y. J., Sageman, B. B., \& Hurtgen, M. T. (2020). Data-model comparison reveals key environmental changes leading to Cenomanian-Turonian Oceanic Anoxic Event 2. Earth-Science Reviews, 203(February), 103123. https://doi.org/10.1016/j.earscirev.2020.103123

Kerr, A. C., \& Kerr, A. C. (1998). Oceanic plateau formation: A cause of mass extinction and black shale deposition around the Cenomanian-Turonian boundary? Journal of the Geological Society, 155, 619-626. https://doi.org/10.1144/gsjgs.155.4.0619

Krinner, G., Viovy, N., de Noblet-Ducoudré, N., Ogée, J., Polcher, J., Friedlingstein, P., et al. (2005). A dynamic global vegetation model for studies of the coupled atmosphere-biosphere system. Global Biogeochemical Cycles, 19(1), 1-33. https://doi.org/10.1029/2003GB002199

Kuypers, M. M. M., Pancost, R. D., Nijenhuis, I. A., \& Sinninghe Damsté, J. S. (2002). Enhanced productivity led to increased organic carbon burial in the euxinic North Atlantic basin during the late Cenomanian oceanic anoxic event. Paleoceanography, 17(4), 31-313. https://doi.org/10.1029/2000PA000569

Ladant, J. B., Poulsen, C. J., Fluteau, F., Tabor, C. R., Macleod, K. G., Martin, E. E., et al. (2020). Paleogeographic controls on the evolution of Late Cretaceous ocean circulation. Climate of the Past, 16(3), 973-1006. https://doi.org/10.5194/cp-16-973-2020

Laugié, M., Donnadieu, Y., Ladant, J., Green, J. A. M., \& Bopp, L. (2020). Stripping back the modern to reveal the Cenomanian-Turonian climate and temperature gradient underneath. Climate of the Past, 2, 953-971. https://doi.org/10.5194/cp-16-953-2020

Li, Y. X., Montañez, I. P., Liu, Z., \& Ma, L. (2017). Astronomical constraints on global carbon-cycle perturbation during Oceanic Anoxic Event 2 (OAE2). Earth and Planetary Science Letters, 462, 35-46. https://doi.org/10.1016/j.epsl.2017.01.007

Loewen, M. W., Duncan, R. A., Kent, A. J. R., \& Krawl, K. (2013). Prolonged plume volcanism in the Caribbean Large Igneous Province: New insights from Curaçao and Haiti. Geochemistry, Geophysics, Geosystems, 14(10), 4241-4259. https://doi.org/10.1002/ggge.20273

Lowery, C. M., Cunningham, R., Barrie, C. D., Bralower, T., \& Snedden, J. W. (2017). The Northern Gulf of Mexico during OAE2 and the relationship between water depth and Black Shale development. Paleoceanography, 32(12), 1316-1335. https://doi. org/10.1002/2017PA003180

Lowery, C. M., Leckie, R. M., Bryant, R., Elderbak, K., Parker, A., Polyak, D. E., et al. (2017). The Late Cretaceous Western Interior Seaway as a model for oxygenation change in epicontinental restricted basins. Earth-Science Reviews, 177(December), 545-564. https://doi. org/10.1016/j.earscirev.2017.12.001

Lunt, D. J., Huber, M., Anagnostou, E., Baatsen, M. L. J., Caballero, R., DeConto, R., et al. (2017). The DeepMIP contribution to PMIP4: Experimental design for model simulations of the EECO, PETM, and pre-PETM (version 1.0). Geoscientific Model Development, 10, 889-901. https://doi.org/10.5194/gmd-10-889-2017

MacLeod, K. G., Martin, E. E., \& Blair, S. W. (2008). Nd isotopic excursion across Cretaceous ocean anoxic event 2 (Cenomanian-Turonian) in the tropical North Atlantic. Geology, 36(10), 811-814. https://doi.org/10.1130/G24999A.1

Madec, G., \& Imbard, M. (1996). A global ocean mesh to overcome the North Pole singularity. Climate Dynamics, 12(6), 381-388. https:// doi.org/10.1007/BF00211684

Madec, G., \& NEMO Team. (2016). NEMO Ocean Engine. Retrieved from http://www.nemo-ocean.eu/About-NEMO/Referencemanuals\$5C\$npapers2://publication/uuid/73E7FF17-99BE-4B10-A823-0037C823EF6E

Martin, E. E., MacLeod, K. G., Jiménez Berrocoso, A., \& Bourbon, E. (2012). Water mass circulation on Demerara Rise during the Late Cretaceous based on Nd isotopes. Earth and Planetary Science Letters, 327, 111-120. https://doi.org/10.1016/j.epsl.2012.01.037

Martinson, V. S., Heller, P. L., \& Frerichs, W. E. (1998). Distinguishing middle Late Cretaceous tectonic events from regional sea-level change using foraminiferal data from the U.S. Western Interior. Bulletin of the Geological Society of America, 110(2), 259-268. https:// doi.org/10.1130/0016-7606(1998)110<0259:DMLCTE $>2.3 . C O ; 2$

McArthur, J. M., Algeo, T. J., Van De Schootbrugge, B., Li, Q., \& Howarth, R. J. (2008). Basinal restriction, black shales, Re-Os dating, and the Early Toarcian (Jurassic) oceanic anoxic event. Paleoceanography, 23(4), 1-22. https://doi.org/10.1029/2008PA001607

Middelburg, J. J., Soetaert, K., Herman, P. M. J., \& Heip, C. H. R. (1996). Denitrification in marine sediments: A model study. Global Biogeochemical Cycles, 10(4), 661-673. https://doi.org/10.1029/96GB02562 
Mitchell, R. N., Bice, D. M., Montanari, A., Cleaveland, L. C., Christianson, K. T., Coccioni, R., \& Hinnov, L. A. (2008). Oceanic anoxic cycles? Orbital prelude to the Bonarelli Level (OAE 2). Earth and Planetary Science Letters, 267(1-2), 1-16. https://doi.org/10.1016/j. epsl.2007.11.026

Monteiro, F. M., Pancost, R. D., Ridgwell, A., \& Donnadieu, Y. (2012). Nutrients as the dominant control on the spread of anoxia and euxinia across the Cenomanian-Turonian oceanic anoxic event (OAE2): Model-data comparison. Paleoceanography, 27(4), 1-17. https:// doi.org/10.1029/2012PA002351

Montoya-Pino, C., Weyer, S., Anbar, A. D., Pross, J., Oschmann, W., van de Schootbrugge, B., \& Arz, H. W. (2010). Global enhancement of ocean anoxia during oceanic anoxic event 2: A quantitative approach using U isotopes. Geology, 38(4), 315-318. https://doi.org/10.1130/ G30652.1

Mourlot, Y., Roddaz, M., Dera, G., Calvès, G., Kim, J. H., Chaboureau, A. C., et al. (2018). Geochemical evidence for large-scale drainage reorganization in Northwest Africa during the Cretaceous. Geochemistry, Geophysics, Geosystems, 19(5), 1690-1712. https://doi. org/10.1029/2018GC007448

Müller, R. D., Sdrolias, M., Gaina, C., \& Roest, W. R. (2008). Age, spreading rates, and spreading asymmetry of the world's ocean crust. Geochemistry, Geophysics, Geosystems, 9(4), 1-19. https://doi.org/10.1029/2007GC001743

Nederbragt, a J., Thurow, J., Vonhof, H., \& Brumsack, H. J. (2004). Modeling oceanic carbon and phosphorus fluxes: Implications for the cause of the late Cenomanian Oceanic Anoxic Event (OAE2). Journal of the Geological Society, 161(4), 721-728. https://doi. org/10.1144/0016-764903-075

Norris, R. D., Bice, K. L., Magno, E. A., \& Wilson, P. A. (2002). Jiggling the tropical thermostat in the Cretaceous hothouse. Geology, 30(4), 299-302. https://doi.org/10.1130/0091-7613(2002)030<0299:JTTTIT>2.0.CO;2

Nouri, F., Azizi, H., Golonka, J., Asahara, Y., Orihashi, Y., Yamamoto, K., et al. (2016). Age and petrogenesis of Na-rich felsic rocks in western Iran: Evidence for closure of the southern branch of the Neo-Tethys in the Late Cretaceous. Tectonophysics, 671, 151-172. https:// doi.org/10.1016/j.tecto.2015.12.014

O'Brien, C. L., Robinson, S. A., Pancost, R. D., Sinninghe Damsté, J. S., Schouten, S., Lunt, D. J., et al. (2017). Cretaceous sea-surface temperature evolution: Constraints from TEX 86 and planktonic foraminiferal oxygen isotopes. Earth-Science Reviews, 172(March 2016), 224-247. https://doi.org/10.1016/j.earscirev.2017.07.012

Ostrander, C. M., Owens, J. D., \& Nielsen, S. G. (2017). Constraining the rate of oceanic deoxygenation leading up to a Cretaceous Oceanic Anoxic Event (OAE-2: 94 Ma). Science Advances, 3(8), e1701020. https://doi.org/10.1126/sciadv.1701020

Owens, J. D., Gill, B. C., Jenkyns, H. C., Bates, S. M., Severmann, S., Kuypers, M. M. M., et al. (2013). Sulfur isotopes track the global extent and dynamics of euxinia during Cretaceous Oceanic Anoxic Event 2. Proceedings of the National Academy of Sciences, 110, 18407-18412. https://doi.org/10.1073/pnas.1305304110

Owens, J. D., Lyons, T. W., Li, X., MacLeod, K. G., Gordon, G., Kuypers, M. M. M., et al. (2012). Iron isotope and trace metal records of iron cycling in the proto-North Atlantic during the Cenomanian-Turonian oceanic anoxic event (OAE-2). Paleoceanography, 27(3), 1-13. https://doi.org/10.1029/2012PA002328

Owens, J. D., Lyons, T. W., \& Lowery, C. M. (2018). Quantifying the missing sink for global organic carbon burial during a Cretaceous oceanic anoxic event. Earth and Planetary Science Letters, 499, 83-94. https://doi.org/10.1016/j.epsl.2018.07.021

Ozaki, K., Tajima, S., \& Tajika, E. (2011). Conditions required for oceanic anoxia/euxinia: Constraints from a one-dimensional ocean biogeochemical cycle model. Earth and Planetary Science Letters, 304(1-2), 270-279. https://doi.org/10.1016/j.epsl.2011.02.011

Palastanga, V., Slomp, C. P., \& Heinze, C. (2011). Long-term controls on ocean phosphorus and oxygen in a global biogeochemical model. Global Biogeochemical Cycles, 25(3), 1-19. https://doi.org/10.1029/2010GB003827

Perez-Infante, J., Farrimond, P., \& Furrer, M. (1996). Global local controls influencing the deposition of the La Luna Formation (Cenomanian-Campanian), western Venezuela. Chemical Geology, 130(3-4), 271-288. https://doi.org/10.1016/0009-2541(96)00019-8

Pogge Von Strandmann, P. A. E., Jenkyns, H. C., \& Woodfine, R. G. (2013). Lithium isotope evidence for enhanced weathering during Oceanic Anoxic Event 2. Nature Geoscience, 6(8), 668-672. https://doi.org/10.1038/ngeo1875

Poulsen, C. J., Barron, E. J., Arthur, M. A., \& Peterson, W. H. (2001). Response of the mid-Cretaceous global oceanic circulation to tectonic and $\mathrm{CO}_{2}$ forcings. Paleoceanography, 16(6), 576-592. https://doi.org/10.1029/2000PA000579

Poulsen, C. J., Seidov, D., Barron, E. J., \& Peterson, W. H. (1998). The impact of paleogeographic evolution on the surface oceanic circulation and the marine environment within the Mid-Cretaceous tethys. Paleoceanography and Paleoclimatology, 13(5), 546-559. https:// doi.org/10.1029/98pa01789

Qin, X., Müller, R. D., Cannon, J., Landgrebe, T. C. W., Heine, C., Watson, R. J., \& Turner, M. (2012). The GPlates geological information model and markup language. Geoscientific Instrumentation, Methods and Data Systems, 1(2), 111-134. https://doi.org/10.5194/ gi-1-111-2012

Robinson, S. A., Dickson, A. J., Pain, A., Jenkyns, H. C., O'Brien, C. L., Farnsworth, A., \& Lunt, D. J. (2019). Southern Hemisphere sea-surface temperatures during the Cenomanian-Turonian: Implications for the termination of Oceanic Anoxic Event 2. Geology, 47(2), 131134. https://doi.org/10.1130/G45842.1

Romito, S., \& Mann, P. (2020). Tectonic terranes underlying the present-day Caribbean Plate: Their tectonic origin, sedimentary thickness, subsidence histories and regional controls on hydrocarbon resources.

Ruvalcaba Baroni, I., Topper, R. P. M., Van Helmond, N. A. G. M., Brinkhuis, H., \& Slomp, C. P. (2014). Biogeochemistry of the North Atlantic during oceanic anoxic event 2: Role of changes in ocean circulation and phosphorus input. Biogeosciences, 11(4), 977-993. https:// doi.org/10.5194/bg-11-977-2014

Sageman, B. B., Meyers, S. R., \& Arthur, M. A. (2006). Orbital time scale and new C-isotope record for Cenomanian-Turonian boundary stratotype. Geology, 34(2), 125-128. https://doi.org/10.1130/G22074.1

Scotese, C. R. (2016). Paleomap paleoatlas for gplates and the paleodataplotter program. Paleomap Project. https://doi.org/10.1130/ abs/2016NC-275387

Séférian, R., Gehlen, M., Bopp, L., Resplandy, L., Orr, J. C., Marti, O., et al. (2016). Inconsistent strategies to spin up models in CMIP5: Implications for ocean biogeochemical model performance assessment. Geoscientific Model Development, 9(5), 1827-1851. https://doi. org/10.5194/gmd-9-1827-2016

Sepulchre, P., Caubel, A., Ladant, J. B., Bopp, L., Boucher, O., Braconnot, P., et al. (2020). IPSL-CM5A2-An Earth system model designed for multi-millennial climate simulations. Geoscientific Model Development, 13(7), 3011-3053. https://doi.org/10.5194/gmd-13-3011-2020

Sewall, J. O., Van De Wal, R. S. W., Van Der Zwan, K., Van Oosterhout, C., Dijkstra, H. A., \& Scotese, C. R. (2007). Climate model boundary conditions for four Cretaceous time slices. Climate of the Past, 3(4), 647-657. https://doi.org/10.5194/cp-3-647-2007

Sinninghe Damste, J. S., \& Koster, J. (1998). A euxinic southern North Atlantic Ocean during the Cenomanian-Turonian oceanic anoxic event. Earth and Planetary Science Letters, 158, 165-173. https://doi.org/10.1016/s0012-821x(98)00052-1 
Soares, D. M., Alves, T. M., \& Terrinha, P. (2014). Contourite drifts on early passive margins as an indicator of established lithospheric breakup. Earth and Planetary Science Letters, 401, 116-131. https://doi.org/10.1016/j.epsl.2014.06.001

Song, H., Wignall, P. B., Song, H., Dai, X., \& Chu, D. (2019). Seawater temperature and dissolved oxygen over the past 500 million years. Journal of Earth Sciences, 30(2), 236-243. https://doi.org/10.1007/s12583-018-1002-2

Stampfli, G. M., \& Borel, G. D. (2002). A plate tectonic model for the Paleozoic and Mesozoic constrained by dynamic plate boundaries and restored synthetic oceanic isochrons. Earth and Planetary Science Letters, 196, 17-33. https://doi.org/10.1016/S0012-821X(01)00588-X

Tabor, C. R., Poulsen, C. J., Lunt, D. J., Rosenbloom, N. A., Otto-Bliesner, B. L., Markwick, P. J., et al. (2016). The cause of Late Cretaceous cooling: A multimodel-proxy comparison. Geology, 44(11), 963-966. https://doi.org/10.1130/G38363.1

Talley, L. D., Reid, J. L., \& Robbins, P. E. (2003). Data-based meridional overturning streamfunctions for the global ocean. Journal of Climate, 16(19), 3213-3226. https://doi.org/10.1175/1520-0442(2003)016<3213:DMOSFT >2.0.CO;2

Thiéblemont, A., Hernández-Molina, F. J., Ponte, J. P., Robin, C., Guillocheau, F., Cazzola, C., \& Raisson, F. (2020). Seismic stratigraphic framework and depositional history for Cretaceous and Cenozoic contourite depositional systems of the Mozambique Channel, SW Indian Ocean. Marine Geology, 425(April), 106192. https://doi.org/10.1016/j.margeo.2020.106192

Topper, R. P. M., Trabucho Alexandre, J., Tuenter, E., \& Meijer, P. T. (2011). A regional ocean circulation model for the mid-Cretaceous North Atlantic Basin: Implications for black shale formation. Climate of the Past, 7(1), 277-297. https://doi.org/10.5194/cp-7-277-2011

Trabucho Alexandre, J., Tuenter, E., Henstra, G. A., Van Der Zwan, K. J., Van De Wal, R. S. W., Dijkstra, H. A., \& De Boer, P. L. (2010). The mid-Cretaceous North Atlantic nutrient trap: Black shales and OAEs. Paleoceanography, 25(4), 1-14. https://doi. org/10.1029/2010PA001925

Turgeon, S. C., \& Creaser, R. A. (2008). Cretaceous oceanic anoxic event 2 triggered by a massive magmatic episode. Nature, 454(July), 326. https://doi.org/10.1038/nature07076

Valcke, S., Budich, R., Carter, M., Guilyardi, E., Lautenschlager, M., Redler, R., \& Steenman-clark, L. (2006). The PRISM software framework and the OASIS coupler. 5(September 2014), 2001-2004

van Helmond, N. A. G. M., Ruvalcaba Baroni, I., Sluijs, A., Sinninghe Damsté, J. S., \& Slomp, C. P. (2014). Spatial extent and degree of oxygen depletion in the deep proto-North Atlantic basin during Oceanic Anoxic Event 2. Geochemistry, Geophysics, Geosystems, 15(11), 4254-4266. https://doi.org/10.1002/2014GC005528

van Helmond, N. A. G. M., Sluijs, A., Reichart, G. J., Damsté, J. S. S., Slomp, C. P., \& Brinkhuis, H. (2014). A perturbed hydrological cycle during Oceanic Anoxic Event 2. Geology, 42(2), 123-126. https://doi.org/10.1130/G34929.1

Van Helmond, N. A. G. M., Sluijs, A., Sinninghe Damsté, J. S., Reichart, G. J., Voigt, S., Erbacher, J., et al. (2015). Freshwater discharge controlled deposition of Cenomanian-Turonian black shales on the NW European epicontinental shelf (Wunstorf, northern Germany) Climate of the Past, 11(3), 495-508. https://doi.org/10.5194/cp-11-495-2015

Voigt, S., Erbacher, J., Mutterlose, J., Weiss, W., Westerhold, T., Wiese, F., et al. (2008). The Cenomanian-Turonian of the Wunstorf section-(North Germany): Global stratigraphic reference section and new orbital time scale for Oceanic Anoxic Event 2. Newsletters in Stratigraphy, 43(1), 65-89. https://doi.org/10.1127/0078-0421/2008/0043-0065

Wagner, T., Damste, J. S. S., Hofmann, P., \& Beckmann, B. (2004). Euxinia and primary production in Late Cretaceous eastern equatorial Atlantic surface waters fostered orbitally driven formation of marine black shales. Paleoceanography, 19(October), 1-13. https://doi. org/10.1029/2003PA000898

Wang, Y., Huang, C., Sun, B., Quan, C., Wu, J., \& Lin, Z. (2014). Paleo-CO2 variation trends and the Cretaceous greenhouse climate. Earth-Science Reviews, 129, 136-147. https://doi.org/10.1016/j.earscirev.2013.11.001

Wanninkhof, R. (1992). Relationship between wind speed and gas exchange over the ocean. Journal of Geophysical Research, 97(C5), 7373-7382. https://doi.org/10.1029/92JC00188

Westermann, S., Vance, D., Cameron, V., Archer, C., \& Robinson, S. A. (2014). Heterogeneous oxygenation states in the Atlantic and Tethys oceans during Oceanic Anoxic Event 2. Earth and Planetary Science Letters, 404, 178-189. https://doi.org/10.1016/j.epsl.2014.07.018

Ye, J., Chardon, D., Rouby, D., Guillocheau, F., Dall'asta, M., Ferry, J. N., \& Broucke, O. (2017). Paleogeographic and structural evolution of northwestern Africa and its Atlantic margins since the early Mesozoic. Geosphere, 13(4), 1254-1284. https://doi.org/10.1130/ GES01426.1

Zheng, X. Y., Jenkyns, H. C., Gale, A. S., Ward, D. J., \& Henderson, G. M. (2013). Changing ocean circulation and hydrothermal inputs during Ocean Anoxic Event 2 (Cenomanian-Turonian): Evidence from Nd-isotopes in the European shelf sea. Earth and Planetary Science Letters, 375, 338-348. https://doi.org/10.1016/j.epsl.2013.05.053

\section{References From the Supporting Information}

Bak, K., Bak, M., Dulemba, P., \& Okoński, S. (2016). Late Cenomanian environmental conditions at the submerged Tatric Ridge, Central Western Carpathians during the period preceding Oceanic Anoxic Event 2 - A palaeontological and isotopic approach. Cretaceous Research, 63, 95-112. https://doi.org/10.1016/j.cretres.2016.02.014

Duque-Botero, F., \& Maurrasse, F. J. M. R. (2008). Role of cyanobacteria in Corg-rich deposits: An example from the Indidura Formation (Cenomanian-Turonian), northeastern Mexico. Cretaceous Research, 29, 957-964. https://doi.org/10.1016/j.cretres.2008.05.015

Elrick, M., Molina-Garza, R., Duncan, R., \& Snow, L. (2009). C-isotope stratigraphy and paleoenvironmental changes across OAE2 (mid-Cretaceous) from shallow-water platform carbonates of southern Mexico. Earth and Planetary Science Letters, 277, 295-306. https://doi.org/10.1016/j.epsl.2008.10.020

Forster, A., Kuypers, M. M. M., Turgeon, S. C., Brumsack, H. J., Petrizzo, M. R., \& Sinninghe Damsté, J. S. (2008). The Cenomanian/ Turonian oceanic anoxic event in the South Atlantic: New insights from a geochemical study of DSDP Site 530A. Palaeogeography, Palaeoclimatology, Palaeoecology, 267, 256-283. https://doi.org/10.1016/j.palaeo.2008.07.006

Gustafsson, M., Holbourn, A., \& Kuhnt, W. (2003). Changes in Northeast Atlantic temperature and carbon flux during the Cenomanian/Turonian paleoceanographic event: The Goban Spur stable isotope record: Paleogeography. Palaeoclimatology, Palaeoecology, 201, 51-66. https://doi.org/10.1016/S0031-0182(03)00509-1

Hasegawa, T., Crampton, J. S., Schiøler, P., Field, B., Fukushi, K., \& Kakizaki, Y. (2013). Carbon isotope stratigraphy and depositional oxia through Cenomanian/Turonian boundary sequences (Upper Cretaceous) in New Zealand. Cretaceous Research, 40, 61-80. https://doi. org/10.1016/j.cretres.2012.05.008

Hetzel, A., März, C., Vogt, C., \& Brumsack, H. J. (2011). Geochemical environment of Cenomanian-Turonian black shale deposition at Wunstorf (northern Germany). Cretaceous Research, 32, 480-494. https://doi.org/10.1016/j.cretres.2011.03.004 
Holbourn, A., \& Kuhnt, W. (2002). Cenomanian-Turonian paleoceanographic change on the Kerguelen Plateau: A comparison with Northern Hemisphere records. Cretaceous Research, 23, 333-349. https://doi.org/10.1006/cres.2002.1008

Lenniger, M., Nøhr-Hansen, H., Hills, L. V., \& Bjerrum, C. J. (2014). Arctic black shale formation during Cretaceous Oceanic Anoxic event 2. Geology, 42, 799-802. https://doi.org/10.1130/G35732.1

Li, G., Jiang, G., Hu, X., \& Wan, X. (2009). New biostratigraphic data from the Cretaceous Bolinxiala Formation in Zanda, southwestern Tibet of China, and their paleogeographic and paleoceanographic implications. Cretaceous Research, 30, 1005-1018. https://doi. org/10.1016/j.cretres.2009.03.005

Li, Y. X., Gill, B., Montañez, I. P., Ma, L., LeRoy, M., \& Kodama, K. P. (2020). Orbitally driven redox fluctuations during Cretaceous Oceanic Anoxic Event 2 (OAE2) revealed by a new magnetic proxy. Palaeogeography, Palaeoclimatology, Palaeoecology, 538, 109465. https://doi. org/10.1016/j.palaeo.2019.109465

Núñez-Useche, F., Canet, C., Barragán, R., \& Alfonso, P. (2016). Bioevents and redox conditions around the Cenomanian-Turonian anoxic event in Central Mexico: Paleogeography. Palaeoclimatology, Palaeoecology, 449, 205-226. https://doi.org/10.1016/j.palaeo.2016.01.035

Sepúlveda, J., Wendler, J., Leider, A., Kuss, H. J., Summons, R. E., \& Hinrichs, K. U. (2009). Molecular isotopic evidence of environmenta and ecological changes across the Cenomanian-Turonian boundary in the Levant Platform of central Jordan. Organic Geochemistry, 40, 553-568. https://doi.org/10.1016/j.orggeochem.2009.02.009

Takashima, R., Nishi, H., Hayashi, K., Okada, H., Kawahata, H., Yamanaka, T., et al. (2009). Litho-, bio- and chemostratigraphy across the Cenomanian/Turonian boundary (OAE 2) in the Vocontian Basin of southeastern France. Palaeogeography, Palaeoclimatology, Palaeoecology, 273, 61-74. https://doi.org/10.1016/j.palaeo.2008.12.001

Takashima, R., Nishi, H., Yamanaka, T., Tomosugi, T., Fernando, A. G., Tanabe, K., et al. (2011). Prevailing oxic environments in the Pacific Ocean during the mid-Cretaceous Oceanic Anoxic Event 2. Nature Communications, 2, 234-235. https://doi.org/10.1038/ncomms1233

Tsikos, H., Jenkyns, H. C., Walsworth-Bell, B., Petrizzo, M. R., Forster, A., Kolonic, S., et al. (2005). Carbon-isotope stratigraphy recorded by the Cenomanian-Turonian Oceanic Anoxic Event: Correlation and implications based on three key localities. Journal of the Geological Society, 162, 576. https://doi.org/10.1144/0016-7649Er161-4

Turgeon, S., \& Brumsack, H. J. (2006). Anoxic vs dysoxic events reflected in sediment geochemistry during the Cenomanian-Turonian Boundary Event (Cretaceous) in the Umbria-Marche Basin of central Italy. Chemical Geology, 234, 321-339. https://doi.org/10.1016/j chemgeo.2006.05.008

Uchman, A., Bak, K., \& Rodríguez-Tovar, F. J. (2008). Ichnological record of deep-sea palaeoenvironmental changes around the Oceanic Anoxic Event 2 (Cenomanian-Turonian boundary): An example from the Barnasiówka section, Polish Outer Carpathians. Palaeogeography, Palaeoclimatology, Palaeoecology, 262, 61-71. https://doi.org/10.1016/j.palaeo.2008.02.002

Valle, B., Dal' Bó, P. F., Mendes, M., Favoreto, J., Rigueti, A. L., Borghi, L., et al. (2019). The expression of the Oceanic Anoxic Event 2 (OAE2) in the northeast of Brazil (Sergipe-Alagoas Basin). Palaeogeography, Palaeoclimatology, Palaeoecology, 529, 12-23. https://doi. org/10.1016/j.palaeo.2019.05.029

Wan, X., Wignall, P. B., \& Zhao, W. (2003). The Cenomanian-Turonian extinction and oceanic anoxic event: Evidence from southern Tibet: Paleogeography. Palaeoclimatology, Palaeoecology, 199, 283-298. https://doi.org/10.1016/S0031-0182(03)00543-1

Wang, C. S., Hu, X. M., Jansa, L., Wan, X. Q., \& Tao, R. (2001). The Cenomanian-Turonian anoxic event in southern Tibet. Cretaceous Research, 22, 481-490. https://doi.org/10.1006/cres.2001.0271

Westermann, S., Caron, M., Fiet, N., Fleitmann, D., Matera, V., Adatte, T., \& Föllmi, K. B. (2010). Evidence for oxic conditions during oceanic anoxic event 2 in the northern Tethyan pelagic realm. Cretaceous Research, 31, 500-514. https://doi.org/10.1016/j.cretres.2010.07.001

Yilmaz, I. O., Altiner, D., Tekin, U. K., Tuysuz, O., Ocakoglu, F., \& Acikalin, S. (2010). Cenomanian-Turonian Oceanic Anoxic Event (OAE2) in the Sakarya Zone, northwestern Turkey: Sedimentological, cyclostratigraphic, and geochemical records. Cretaceous Research, 31, 207-226. https://doi.org/10.1016/j.cretres.2009.10.005

Yurtsever, T. S., Tekin, U. K., \& Demirel, I. H. (2003). First evidence of the Cenomanian/Turonian boundary event (CTBE) in the Alakirçay Nappe of the Antalya Nappes, southwest Turkey. Cretaceous Research, 24, 41-53. https://doi.org/10.1016/S0195-6671(03)00021-1 